\title{
THE WILD-FOWLERS
}
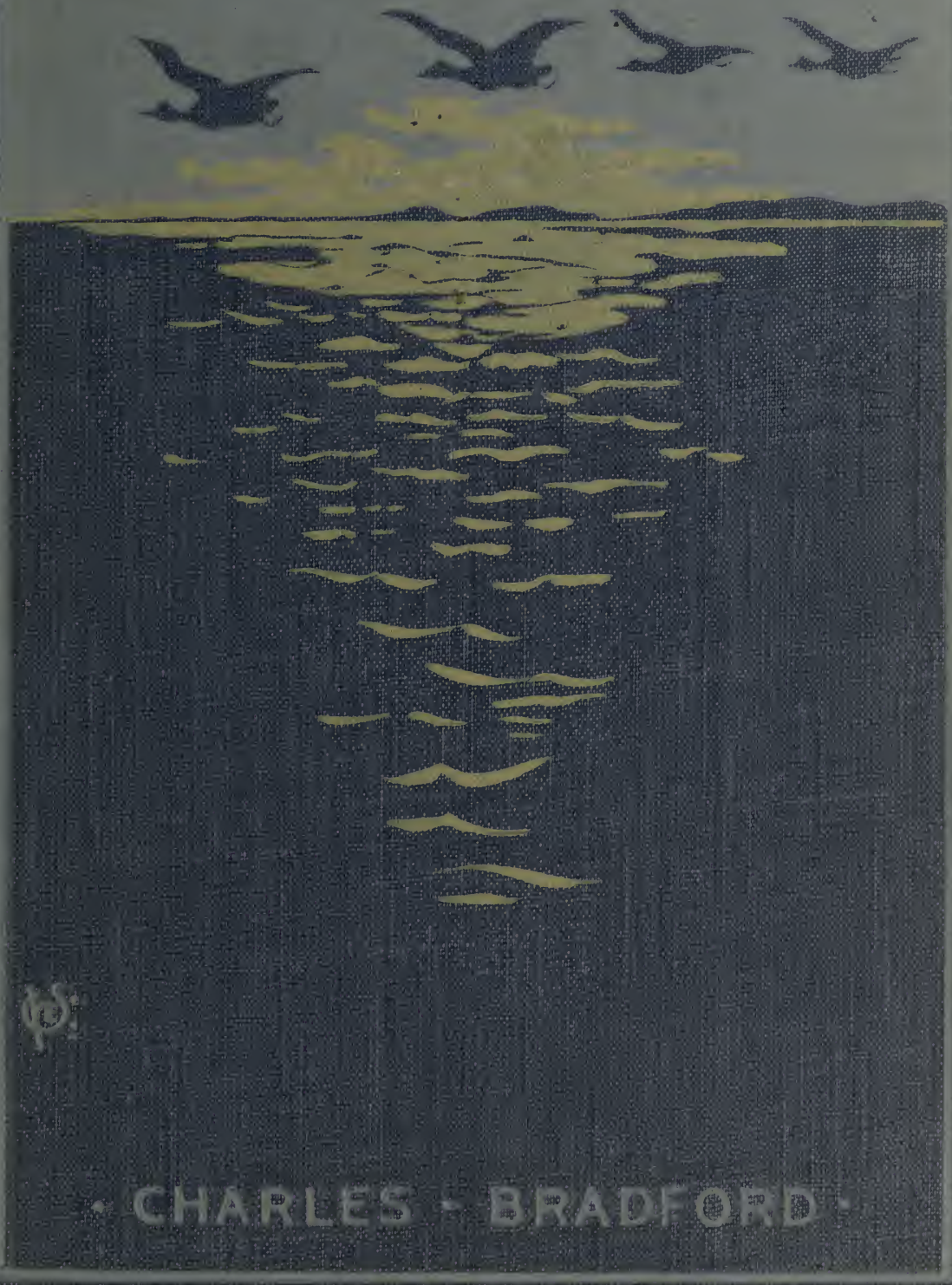


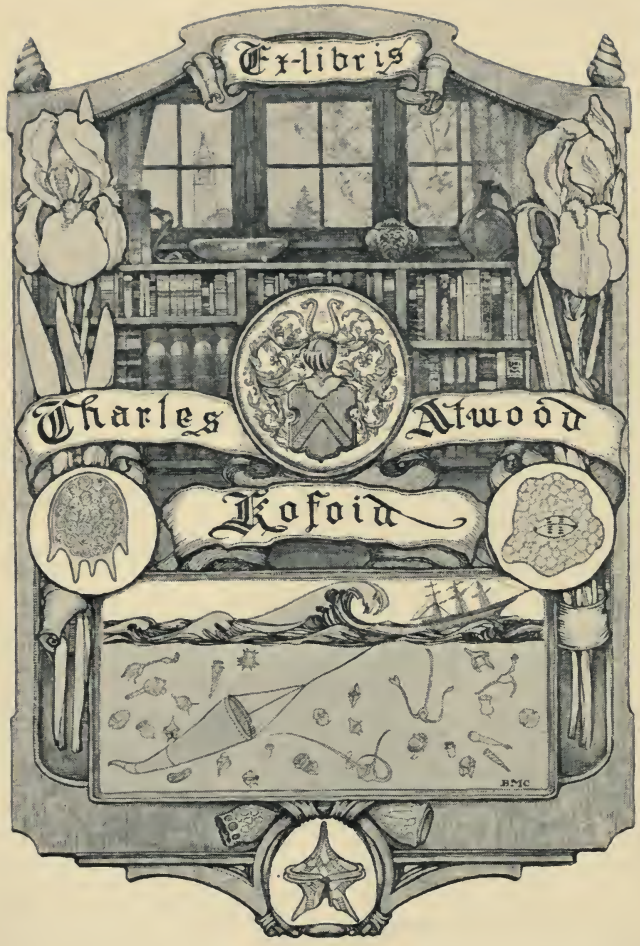




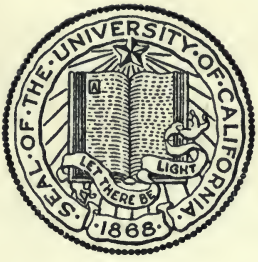

THE LIBRARY OF THE UNIVERSITY OF CALIFORNIA

PRESENTED BY PROF. CHARLES A. KOFOID AND MRS. PRUDENCE W. KOFOID 

Digitized by the Internet Archive in 2007 with funding from Microsoft Corporation

http://www.archive.org/details/wildfowlersorspo00bradrich 


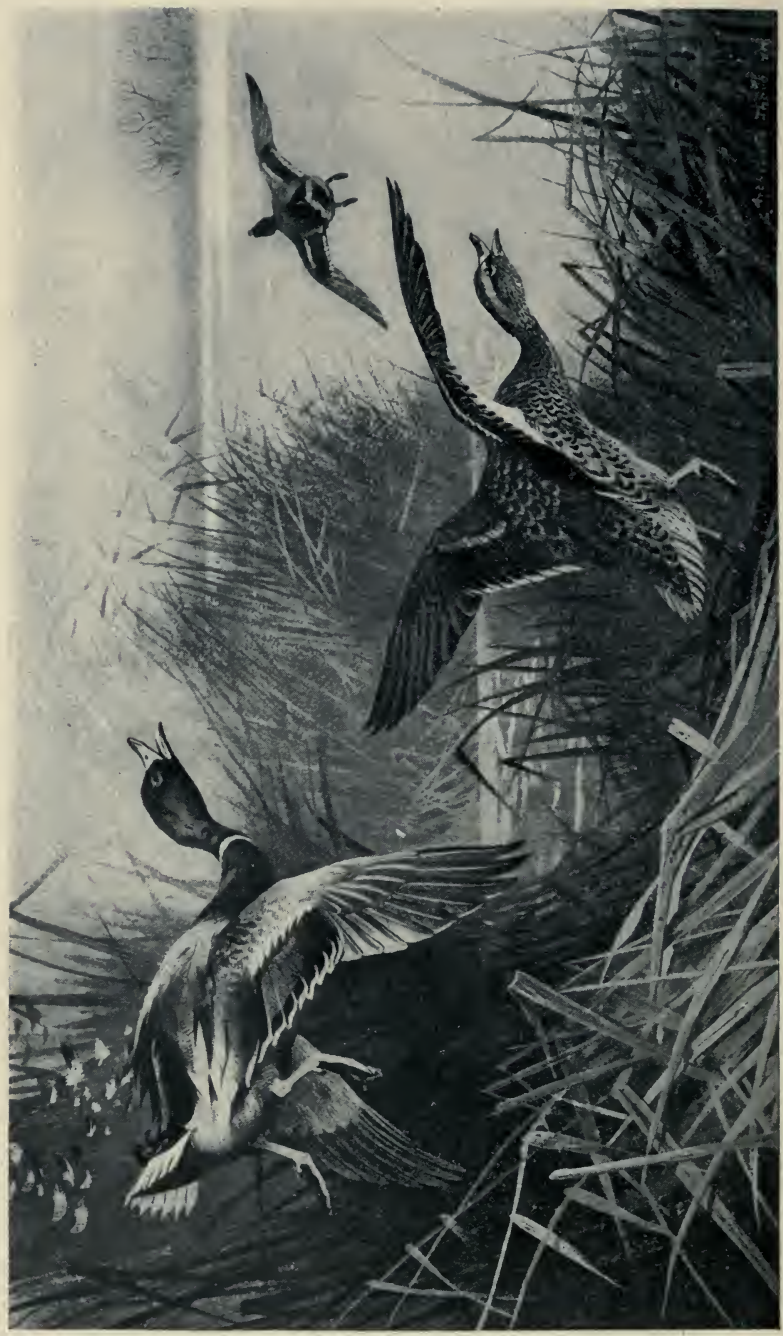

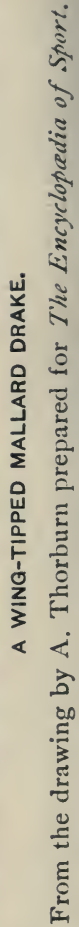




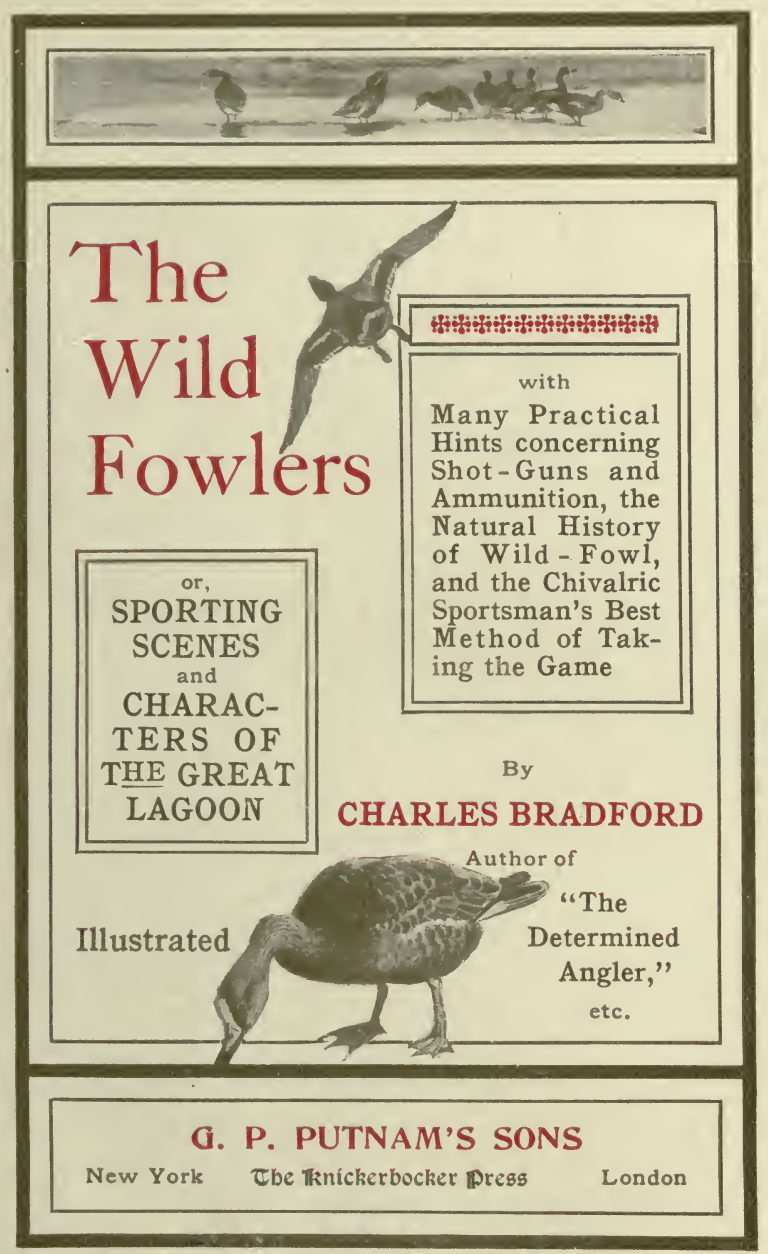


Copyright, igor

BY

CHARLES BRADFORD

Tbe tinickerbocker Press, Mew Lork 


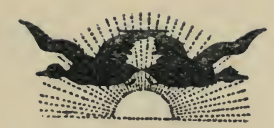

To

\section{GROVER CLEVELAND}

A SPORTSMAN AND NATURE LOVER OF RARE QUALITY

THESE LITTLE CHAPTERS ARE RESPECTFULLY DEDICATED 



\section{$S K 3 / 3$ B7}

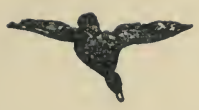

\section{CONTENTS}

I.-Point Shooting for BlackDUCK • . . . . 3

II.-The Sportsman's LaIR . - 3I

III.- "The Quick AND THE DEAD" 53

IV.-The Merrick Road . . 65

V.-Cap'in Grieb, Bayman . • 87

VI.- "Rocked in THE CRAdLE OF THE DEEP" . . . . 99

VII.-Seth Fielding's First Lesson in Battery Shooting . II3

VIII.-The Bayman's Choice . • 133

IX.-The Contemplative SportsMEN • • • • . 147

X.-The Last Chapter . . I63

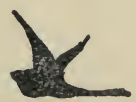





\section{I}

Point Shooting for Blackduck 


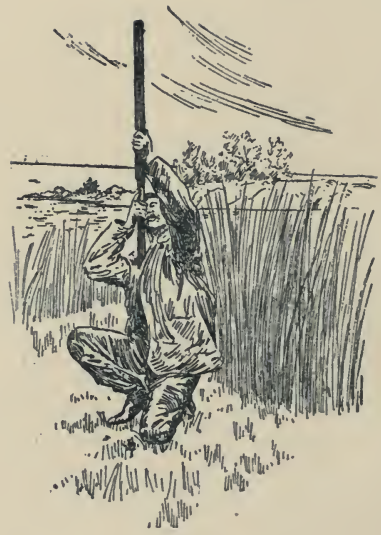





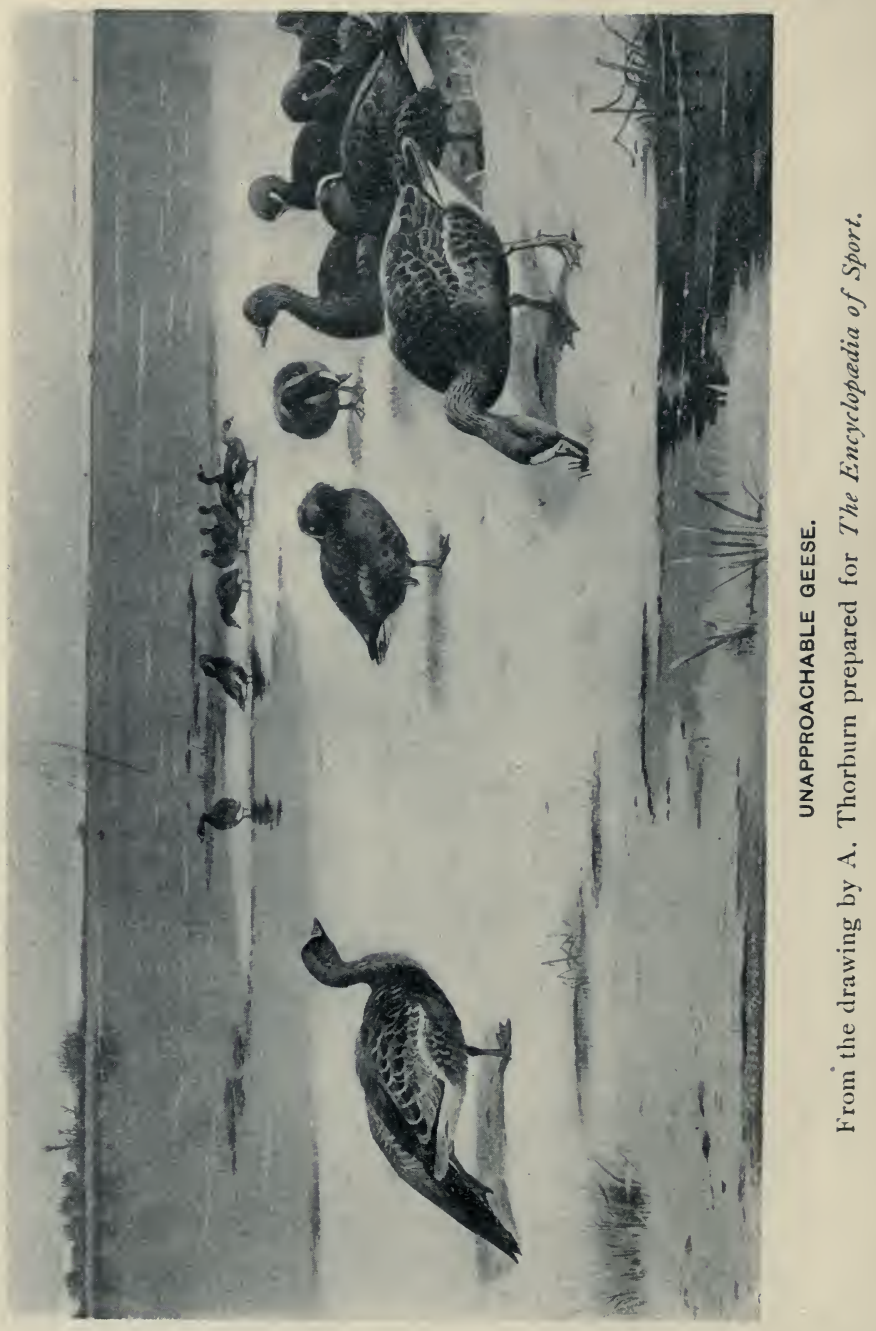




\section{I}

\section{Point Shooting for Blackduck}

"Reading and writing are inflicted by schoolmasters, but a crack shot is the work of God."Frank Forester.

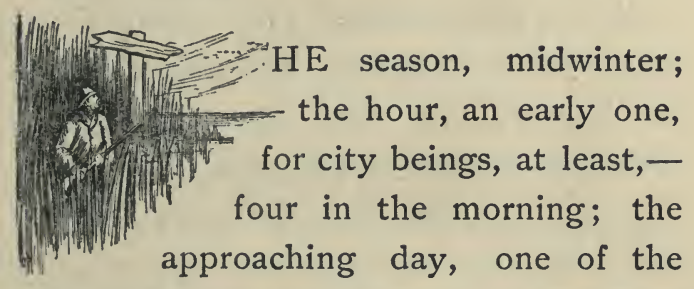
midweek, with full promise of crispness and brightness; the place, aboard a sturdy sloop, making out the little creek at Amityville into the open water of the Great South Bay of Long Island; the company, one Adam Grieb, skipper, who has "follered th' bay nigh on teh sixty year an' more"; Doctor Edward Bradley, who, though a city man, looks as strong and weather-stained as the bayman; and Peritus, the Doctor's young companion. 
We will follow the course of these jovial guns in a half-day's gentle sporting on a point for blackduck. The crisp air and brisk exercise will stir our tired lungs and stiffened limbs to better action, and the mind will enjoy the exhilaration of the genial pursuit.

"You see, Peritus," said Doctor Bradley, " we start at four, two hours before daylight, as we must be on the point nicely concealed and with all the decoys rigged out before the light o' day affords the blackduck too great an opportunity of seeing our movements. He has the eyes of an eagle for distance and can see in the dark as well as the cat and owl."

"Why not start the night before and sleep on the way to the shooting-ground, as we do in bay snipe-shooting, and as Captain Liebnow took us out when we shot from the battery? This morning cruise is a bitter cold one," said the boy.

" W'hy, we sail in th' mornin' 'cause we haint a-goin' es fer, 'cause th' nights 
be longer now, and 'cause thar beant no 'vantage nohow in a-goin' earlier," replied the Captain. " We mote es well ' $a$ ' sailed in th' night, genelmen, had yer wished it, though; I allus do it in th' summer an' when I go out with th' battery."

"Ah, boy, you must stand the cold," said Bradley; "the sport pays for it. This is the great season for birds, though the tyro finds more comfort in gunning at a less hardy period-October and early November. But our weather-beaten baymen and their experienced patrons will agree that the birds are more plentiful and better-conditioned in midwinter, so long as the great lagoon is not frozen over. Am I not correct, Captain ?"

"Kerrect yer be, Doctor Bradley."

" Now, Peritus," continued the Doctor, "I 'll play skipper, while you and Captain Grieb prepare the breakfast, and don't be afraid of the coffee, Captain. Give us plenty of it. You baymen know 
all about tides and clamholes, some of you know a little about ducks, but there is n't one of you who ever tasted a real cup of coffee-I 'll make it myself!' and the fat Doctor forthwith crouched down into the tiny cabin, and soon had Peritus as busy with the pots and dishes as old Grieb had been with decoys and rubber boots at an earlier hour.

Refreshed by an immense quantity of bacon, eggs, toast, broiled broadbill, and the Doctor's excellent coffee, our three friends made ready to anchor the sloop" put the hook over," as the Captain expressed it -and launch a smaller craft, the deadgrass-lined dingy, in which the fowlers were to spend the morning snugly hidden in the high salt meadow grass of the selected point.

"I 'll put you genelmen in shape, and then move away a mile er so in th' sloop," said Grieb, as he towed his two charges toward the point of meadowland, the old fellow standing in the centre of a 


\section{The Wild-Fowlers}

still smaller craft, shoving it and the towed dingy with a ten-foot pole-the " stick," as he described it to Peritus.

The gunners were made comfortable with rough gray blankets and hay; dead grass was piled up all about their boat to make the hiding-place as little conspicuous as possible, and the troop of decoys, numbering fully half a hundred, with an equal scattering of blackduck and redhead, were nicely arranged in the shallow tide-water in front of the now eager sportsmen.

" Now, genelmen, I says es ye 'd bes' not smoke fer haf a hour till we see es what 's in this part o' th' bay," were the old Captain's parting words as he shoved away toward the sloop.

"All right, Captain," replied Doctor Bradley; " have a good meal for us at ten o'clock-some little-necks, bluepoints, a baked cod, and a lot more roast duckdown, Peritus! What 's that bunch off east, Captain?" and the Doctor and his 
young friend hid down snugly in the hay at the bottom of their shelter, as the old bayman shouted back:

' Broadbills, an' a-comin' this way, sure es eel-pots! Down, genelmen! Down like fiddler crabs! Ye 'll get a shot teh unct er my name beant Capem Grieb!"

Far off in the gray east, twenty birdsbroadbill, as the Captain truthfully identified the species-could be plainly seen, bunched like blackbirds and coming surely nearer and nearer the hidden enemy. Captain Grieb poled hastily toward the sloop, and, arriving too late to move the conspicuous craft, did the very next best thing-crouched down in the bottom of his little dingy, close to the dark side of the larger boat, and muttered to himself :

"Broadbills beant point birds in this bay 'cept at 'tickler 'casions, an' th' chances beant good fer th' Doctor teh git 'em inter th' decoys." 


\section{The Wild-Fowlers}

But it proved to be a " 'tickler 'casion," and the plump little bunch went right smack into the wooden flock of floating imitative fowl, and-bang! bang! boom! boom! echoed over the water and up against the side of the sloop.

"Hooray teh yer, genelmen!" fairly yelled the ruddy skipper as he stuck up his shaggy head over the edge of his dingy, just as three dead broadbills dipped into the water and slowly drifted in the tideway. "Yer shootin' mighty strong, fer fair; I ain't seed eny broadbill come inter a point a like that in sixty seasons; who be a-shootin' that blackpowder gun ?-you, Doctor Bradley, I 'll bet a bushel o' clam, rake and all."

"Yes," cried the Doctor, flushed and excited at so good a start; “yes, I 'm shooting black powder, but just to show Peritus the difference in the old and the new brands, that's all. Peritus got a bird, Captain, the first as came down. He missed with his first barrel-I knew 
he would, for he shot at the whole bunch. But he got one nicely with the second discharge, as he picked out his bird. I made a double easily, but my! they were going all right when I gave the last trigger!"

The Captain had by this time picked up the fowl and was off again toward the sloop, which he soon had under way, the old boat's mainsail breaking out heavily in the mild morning wind-a steady nor'wester-as the clumsy craft slowly legged it to the east, the bayman, all smiles, waving his cap as a parting salute to his two friends.

"Peritus, I never killed a broadbill from a point before to-day," said the Doctor to his young friend as they both got down snugly again out of sight in the hay and blankets, " though I have of ten had them cross the decoys and shot at them at long range. We 're very lucky. How I wish Seth Fielding could see this!" 
"The broadbill is a battery bird, I know," replied the young man, " at least here in the saltwater localities, but out West, where we know them as the bluebill and blackhead, they are shot at from a point as commonly as redhead, canvasback, butterball, mallard, pintail, and the other birds; are n't they ?"

"Quite true, Peritus. I have myself enjoyed the sport, but here, as you say, they are better killed from a battery, and are as seldom taken over a point as the blackduck is bagged from the sink-box. We shall have sport to-day. I like the conditions."

The two men lighted their pipes and enjoyed the fumes of fragrant plug-cut tobacco, as they conversed in low tones, the older man not for a moment neglecting to keep careful watch on all sides.

Far to the eastern point of the bay, quietly riding on the shallow water's surface, like an immense raft of small wood, the eye could plainly discern a great body 
of ducks, mostly broadbill and "coot" (scoter), with one or two small bunches of blackduck riding a short distance from the other fowl, and at least twenty brent geese (" brant") skirting the great flock to the north; and a half-mile this side of the water flock, Captain Grieb's sloop loomed up plainly as the old craft made to the south of the birds, the Captain intending to disturb the fowl and drive them within range of the two gunners.

The sun had not risen, but the eastern heavens began to take on that reddishgolden hue, and a smarter breeze, now breaking out, cleared away the clouds of mist that had hung over the great body of water. Soon huge bars of warm sunlight shot up in the sky directly in front of our sportsmen's point, and all that remained of the dull gray of early morn was slowly fading in the far west.

"That big flock will get up now, Peritus," said the Doctor, bending over lower 


\section{The Wild-Fowlers}

than ever and peering through the tall grasses that lined the cozy hiding-place, as his companion proudly imitated the movement, " and we must prepare to make the most of the situation. Now, boy, don't shoot into the body of the flock, nor at the leader birds, else you frighten the whole flock and thus ruin our sport for the day. Let the great cloud of birds go by and then pick two of the last bunch. I will fire after you have given trigger. If we shoot at the fowl in the front, all those that follow will leave this part of the bay. The flock will not be bunched. The birds string out in a line a mile or more long and pass in small bunches. You'll become excited and want to shoot at the leader bunch, but don't do it ; restrain yourself ; our day 'll be better for it. The brant will get up first, circle in the air, and tail along with the last birds to take wing. All of the blackduck will come head on, bangetybang into our decoys, and a lot of them 


\section{4 \\ The Wild-Fowlers}

will light among the stool. Let 'em do it; don't you shoot till I tell you-till the great mass has gone by. Then kill a rear bird in the last bunch, and with your second barrel I shall look for you to stop one of the blackduck that will get away from the decoys. I 'll try for redhead and broadbill. The brant won't come in at all, so we need n't bother about them."

"Are you sure there are brant there, Doctor? I thought brant frequented the bay only in early spring - March and April," and Peritus brought his gun-a handsome double fowling-piece of twelvegauge-out from the hay and stuck the muzzles through the blind grass, his companion having already adjusted his favorite arm-a ten-gauge of full nine pounds.

The Doctor did not answer, but instead signalled his young friend in pantomime familiar to companion gunners to keep quiet and well down. A pair of sprigtails approached from the rear and went over 


\section{The Wild-Fowlers}

the shooters' heads at great height and speed, but their wings whistled so plainly that the old man was startled for a moment.

"Ha! Mr. and Mrs. Pintail, good morning to you!" laughed the old Doctor, as he again glanced in the direction of the bayman, who steadily neared the great flock of fowl on the water.

"Yes, Peritus," said he in a half whisper, " there are brant among them, but, as you say, the brant are mostly plentiful in these waters in early spring. The mild weather accounts, perhaps, for these few remaining so late in the season. Hush, boy!"

As he uttered this sharp warning, his left hand stole softly to Peritus's knee and the two fowlers crouched down lower than ever, grasped their guns nervously, and stared wildly out in the great space beyond the decoys. The birds began to rise,-the brant first, as the Doctor predicted,-and old Grieb had brought his 
sloop about so that the clumsy mainsail was flopping wildly in the breeze.

" Remember, Peritus," whispered the Doctor excitedly to the boy beside him, as three couples and a half of redhead shot by the decoys at a mile-a-minute clip,_- "don't you move till I tell you! Down, down, on your belly, closer still!"

Following the redhead came the first two bunches of broadbill, and from then on the wild fowl filed over, around, and on all sides of the decoys and the very blind and its occupants. Poor Peritus was ever on the verge of giving way to the severe strain he was subjected to, and his companion more than once restrained him.

The scene was a charming one to both the tyro and the experienced man. Brant, broadbill, blackduck, redhead, " coot" (scoter), sprigtail, old squaw, and sheldrake all wheeled by in small platoons, some skimming over the decoys, others far out beyond the head of the stool, 


\section{The Wild-Fowlers}

many quite over the blind, and nearly every bird within gunshot and but a foot or two above the water.

" Steady, boy!" whispered the Doctor, disturbed by Peritus's excitement. "Take the safety off, and be ready; your bird is coming! There! Here are the blackduck! See them 'light!" and the old man's cheeks glowed with youthful flame and his eyes glared and danced as he nervously patted Peritus on the leg.

Five couples and a half of beautiful blackduck, their ruddy feathers glistening in the early sunshine, skimmed into the very centre of the flock of imitation fowl, set their wings fully outstretched, lowered their feet, and dipped into the salty bay with the graceful ease of a brood of swans putting out into some mansion pond.

Other bunches of the same species went on with the great line of birds, and innumerable brant couples, trios, and half-dozen sets circled about in the air on all sides, 
but never near by, and with a low but steady drifting with the general flight.

"The last birds are too far out, Peritus," cried the Doctor, " so take you this right broadbill coming in the bunch of five! Hold a little ahead-they are not swiftly going-ignore the bunch and pull with your gun in motion! Then with your second barrel take you the first of the blackduck that rises from the decoys. Do not mind me. A foot ahead will do on the broadbill! Mark him well, steady now, there! let drive, boy! He 's yours!"

Peritus fired, a foot ahead, as his companion ordered, and the fowl keeled over, killed quite dead, and splashed into the water, driving the spray three feet into the air, and wetting the decoys with a sparkling shower. Then, rapidly swinging the gun to the left, the young fowler gave trigger at a towering blackduck, but missed the bird by a full half foot, shooting under and too far to the left.

The Doctor scored a double, a couple 
of redheads tumbling to his discharges and dipping into the bay as dead as Peritus's first bird, which, with the Doctor's pair, floated in the gentle tideway forty yards from the blind.

" Well done, Doctor!" cried Peritus, crouched again and slipping in fresh cartridges; "well done! but I suppose you 'll thrash me for missing the blackduck."

"No, Peritus! Never! You did as well as a hundred other fair shots could have done under the circumstances, but you erred, boy, as I 'll presently explain to you-no more black powder for me today, though I did wish to use up these quarter-hundred shells and at the same time experiment with both the old and the new brands for your benefit; but it kicks unmercifully and there is n't wind enough to take away the smoke nicely so as to clear the range for the second barrel. I did n't mind the recoil in the old days, somehow, and the smoke was never troublesome," and the Doctor was 
hurriedly tossing away the black-powder cartridges and extracting half a hundred nitro loads from his sole-leather ammunition box.

"You see, Peritus, I could avoid the smoke nuisance of the black powder by using nitro in the first barrel, and I 'd do this if the blamed blacks did n't kick so; my shoulder's quite sore from those two first shots, and, strangely, too, for I have in olden times used up fifty of the same load in a morning without noticing any recoil. The white powder has spoiled me, I guess."

"Do you believe it is as good as it is claimed ?"

"Assuredly; it is the powder. In its first state it was like all new inventions-crude, but nowadays no man should use anything else in the powder line. It shoots as quick and strong as the old stuff, if not quicker and stronger. The gun does not recoil as with black powder; the shooter's chance of making 


\section{The Wild-Fowlers}

a second shot is enhanced fifty per cent. by the absence of smoke from the first discharge, which, in the old load, was so dense in still weather as to completely hide the game. Besides, the noise made by the new material exploding is just about half what the old brand made. The noise and recoil of olden days would give me a headache and a lame shoulder now."

" And," -asked Peritus, still carefully looking up and down the bay for any fowl that might be on the wing, - " and is not the new powder cleaner to the gun ?"

"Much, both in the barrels and around the breeches. One day's shooting with black powder will muss a gun more than ten days' work with nitro-down! Mark south! Coot; let 'em go; don't they look like brant? They 're coming in; we 'll let 'em 'light but not disturb them; their flesh is rank, though at certain times of the year their breast, cleanly skinned, broiled, and served with onions, is as 


\section{The Wild-Fowlers}

good as any wild meat. There 's some broadbill going southwest, Peritus; they 'll not come in, but here 's our coot, four of them. See them set their wings and lower their great webbed feet-what an easy shot! That's the time to take all lighting fowl, boy, just at the moment they flutter down, wings set, and feet outstretched. Any boy or cheap-arm gunner can kill a lighting duck if they 'll wait for that particular moment."

"I believe you, Doctor; I once saw a man kill a sheldrake with a twenty-two rifle ball, firing just as the bird's webs touched the decoy hole, and the shot put the ball clean through the fowl's breast. Captain Emeigh of Bellmore saw this, too, and he will also tell you that it is not impracticable to shoot duck with a small rifle if the shooter will wait for the lighting birds. I am-" but Peritus finished not his sentence. A bit of spirited pantomime by his companion moved him to silence, and the two men got down close 
and with excited eyes watched the approach of a bunch of ten blackduck that were coming head-on fully a half-mile away.

"If they cross, Peritus, take you the last bird, as they will pass you first and come to me last; that is the rule, boy. If they attempt to 'light, pick the spreading bird on your side, and then, as they go away, take any bird you like. Fire not at the bunch-that 's the cockney's practice, and it always fails. Pick your birds in all cases."

On came the great fowl winging but five feet above the water's surface, and, instead of coming head-on or attempting to cross, the entire bunch sailed around to the south a hundred yards out from the decoys, and, coming up against the mild wind, set their wings and dove down into the very centre of the decoy fleet, coming from the Doctor's side. It was, therefore, Peritus's first shot, and he took it at the leader bird, doubling up that 
gamester with a full ounce of shot, as it seemed, while the Doctor pulled at a pair that were lined up at the same moment, and both collapsed at the snap of his gun. Both men then gave second trigger at separate single birds, now wildly upon the wing, but only one fowl was stopped, and this by the older man's shot.

"Four in five shots, boy. And blackduck at that! What think you-are we not very sober or very lucky, or both ? Enthuse, boy, enthuse! Oh, if Doctor Corbin and Seth Fielding could see this!"

" I can't hit my second birds," replied Peritus, plainly annoyed at his second miss with the second barrel.

" But you will when I tell you the trick, and I 'll do so now. I wanted you to see the mannerisms of the blackduck a little more than was afforded by the first of that species that came to the stool. Have n't you observed a particular trait in the blackduck's leaving the decoys ?" 


\section{The Wild-Fowlers . 25}

"No, but I notice that I shot too low in each case."

"Quite so. The blackduck, Peritus, is the woodcock of the water. Unlike other ducks, he towers when he leaves the decoys-when he takes wing in any instance. Most fowl simply get away in any manner, when startled-they scurry off any old way just so as to get away as fast as their wings will take them, but the blackduck jumps like a woodcock when he is startled, springs at times twenty feet in the air with one flap of the wings, and if you do not appreciate this trait you are sure to miss him by shooting too low, as you did in both cašes here today.'

The two men thus chatted and gave trigger up to ten o'clock, when the Captain poled up in his dingy, ostensibly to retrieve the game, but taking good care to hint to his two charges at the same time that lunch hour was near at hand and lunch quite ready-."ef you genelmen 
be a-willin' teh leave off gunnin' fer feedin'," as he remarked with a broad grin and an elaborate salutation with his brawny left arm. The Doctor and young Peritus went aboard, and for over two hours the three men ate, drank, smoked, talked, laughed, and sang in that peculiar spirit of good nature only known to sportsmen.

Both of the elder men related experiences with rod and gun, to the extreme delight of their young companion, and many a practical bit concerning guns, ammunition, wild fowl, and natural history in general was brought out for his especial benefit. Old Grieb told how the blackduck went up into the creeks and ponds to feed whenever the tide made low at dark or very early in the morning; how he had often come upon a great flock of them in the ocean- " outside," as he termed it-all fast asleep in the middle of the day, which, "teh those es hed follered the bay," as he put it, meant that the 


\section{The Wild-Fowlers}

water in the bay and creeks was low at dark or "dreffel airly in the mornin" "; how the different species of wild fowl acted in the bay at all seasons of the year; what they fed on, where they slept, and how they were taken by the gunner, and Doctor Bradley related many of his experiences both afield and afloat, so that Peritus, by the time he and the Doctor returned to the blind, felt he had devoured quite his share of mental food if the Doctor had beaten him with knife, fork, and goblet.

"Good-bye, Peritus," said Doctor Bradley, at the end of the day, when the two had reached the city. "You 're a first-class shooting companion, and I 'm going to introduce you, some day, to Fielding and Corbin, who 'll give you better sport than I am capable of."

"Good-bye, Doctor. I 'll appreciate the introduction to your two famous friends, and profit greatly by their society, but I won't allow that they 'll give 


\section{The Wild-Fowlers}

me a better day than this has been with you, old friend. Good-bye, good-bye."

"With the non-shooting public, every man who can shoot on the wing is a sportsman; the man who can follow the track of a quail in the cornfield as an Indian can track a deer in the forest, who exterminates a bevy of birds at a single shot, is a sportsman; he who slaughters hundreds of fowl in and out of season is also a sportsman, and, knowing no difference between these and their betters of the gun, the indiscriminating public classes them all alike."-GLOAN.

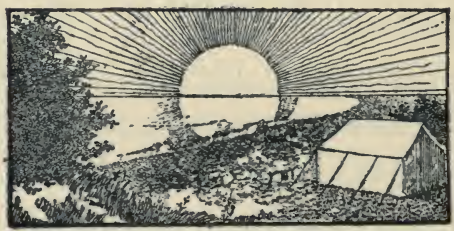


The Sportsman's Lair 
* 
The Sportsman's Lair

"All the sports of the field are delightful, I own, But none with shooting compare ;

' $\mathrm{T}$ is a joy that entices the king from his throne,

'T is a joy the wisest may share."

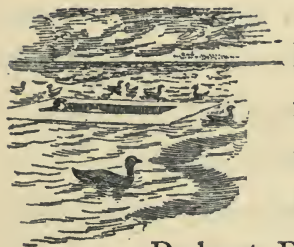

ETH FIELDING had never shot from a battery, but he had read Frank Forester's and Robert B. Roosevelt's condemnation of the practice, so it was natural for him to refuse at first to accompany his two friends, Doctor Bradley and Doctor Corbin, who proposed a trip for brant and broadbill.

“Pray tell me," said Doctor Bradley, " how you know so much about the matter when you acknowledge that you have never had any experience in the sink-box. How do you know whether it is cruel, 
destructive, and altogether unsportsmanlike, or 'first-best sport,' as Tom Draw would say? Come, now, shut that desk down, get your traps together, and meet Doctor Corbin and me at luncheon at the Studio to-morrow."

"No, sir," responded Seth, closing his lips firmly; "I won't do it, and furthermore, I 'm going to do all I can to put down the murderous pursuit. Battery shooting is the worst sort of game slaughter; the birds that are not killed outright by the shooters are made cripples or frightened away for good. I say for good, meaning forever, because the slaughter is done on the fowls' actual feeding-grounds, on open water, too, and no duck is going to stay very long where it is fired upon by an enemy who can conceal himself without any apparent shelter. Besides, you 're going shooting in the springtime, when the birds are on their way to the breeding-places, as you well know, and I don't believe in this extrava- 


\section{The Wild-Fowlers}

gantly destructive practice. I won't go. Have a smoke ?" And Seth handed his friend a Key West favorite and lighted one himself.

"All you say may be true, Seth," quoth the Doctor, " but you 'd best make sure of it. You 've never been in a battery. Here 's your chance. The birds are in the bay, the legal season is still on. Doctor and I have engaged Captain Grieb of Amityville for two days, and the train goes at three o'clock to-morrow. We 'll lunch early, say twelve o'clock. The trip 'll do you good, and I promised the Doctor you 'd join us. Think of two days and two nights on that grand old bay, boy! Think of it! We 'll make this the last spring trip. We 'll go out there especially to investigate matters, get practical points on the details you speak of ; then, if you 're right, the Doctor and I will give way to you. But, since you 're talking without actual knowledge you must listen to us. The 
fact is, Seth, we, too, are against spring shooting, and we want you to post up a bit on it and then join us in a stampede against the practice. The law is wrong in permitting duck shooting after the autumn and midwinter seasons. As for battery shooting, you may be right about its being too destructive, but the Doctor and I have not been in the sink-box often enough to either deny or affirm this statement. You join us in this trip, and we 'll abide by your decision. We need n't kill a greedy mess-just a couple or two, and have a good general outing. I give you my word this will be the farewell spring trip; no shooting beyond that which the autumn and midwinter seasons allow after this, and never again at any time in the battery, if you decide against it-after you 've judged the practice from actual experience."

"Well, this is very flattering to me, Doctor, and I 'm

"Think of the time we 'll have in that 
fine old bay, boy! The Captain 's a great cook and a great character-equal to anything Dickens ever pictured-and you must see him. His sloop is a comfortable old-timer of forty feet, and we 'll live sumptuously - plenty of oysters right from their beds, clams galore, and fried flounder and eel, broiled fluke, roast duck, and, and-well, lots of other good things, including our Key Wests and the Doctor's usual supply of moist material. You need n't actually shoot from the battery. The Captain 'll rig you out on a point for blackduck and sprigtail, and you 'll have great sport. Besides, you 'll be able to verify all that your friend Forester says against the battery. Say, Seth," continued the Doctor in a humorous whisper, "they tell me Forester was never in a battery-ha! ha! you writing cusses cry down pursuits you know nothing about-you go off half cocked. Somebody who can't afford a sloop and battery, and who 's down on somebody 
who can, tells you battery shooting is slaughter, and you cry it down in print without further investigation. I 'm surprised that some persons who have enemies in yachts and carriages don't say boating and driving are cruel pastimesin fact, they do say it-the anarchists say it."

The Dortor here laughed louder than ever, and, slapping Seth soundly on the shoulder, continued:

" Now, don't back out, old boy. Be at the Studio at twelve sharp. I 'll have the wagon there at one-thirty, and William 'll be on hand to look after the traps."

"Well, I could n't possibly back out, Doctor," said Seth, " as matters stand, because I have n't agreed to go. But I think I will go. Your laugh about the report that Forester never shot from a battery and the suggestion that I shoot blackduck from a point have altered my mind on the subject. Yes, I 'll go. I 'll 
satisfy myself that Forester was right in condemning the pursuit, whether he indulged in it personally or not, and I 'll wager with you now that I shall not change my views after I have been on the ground. One need not become a burglar himself in order to condemn thievery. I don't remember whether Forester did any battery shooting or not, but I do know he strongly argued against it, and that Roosevelt was an old bayman, and he certainly knew what he was talking about. $\mathrm{He}$, more than any one else, disfavors the practice, and his reasons are sound. Here 's his book. Listen to this paragraph," and Seth reached for the volume, which was quickly lifted from a floorshelf that contained a full two hundred works on field sporting, angling, and natural history. Then, as the Doctor relighted his cigar and stretched himself out comfortably over three quarters of the immense lounge he always selected when in Seth's den, he read as follows: 
"At present we suffer more from improper modes of pursuit than from absolute scarcity of game. The habit of using 'batteries' in the South Bay of Long Island, and locating them on the feedingor sanding-grounds, has resulted in frightening away the birds. Where, a few years ago, ten ducks stopped in the water adjoining that famous sand-pit, there can hardly be found one at present. After being disturbed on their feeding-grounds by murderous discharges from an unseen foe in their midst, they become alarmed and leave the locality altogether. To be sure, for a year or so, the number killed from that ingenious mode of ambush will be enormous; but it is at a terrible sacrifice of the supply, and will eventuate in ruin to those engaged in it. At present on Long Island it is hardly possible to obtain a decent day's sport without using a 'battery'; but in the South, along the Chesapeake and Potomac, where the use of these inventions has never been al- 


\section{The Wild-Fowlers}

lowed, the ducks are as abundant as ever."

" Now stop a minute, Seth," said the Doctor, shaking his cigar at his friend much as he would shake his forefinger. " He says that at present it is hardly possible to obtain a decent day's sport. Well, I say he 's off on that ground-the ducks are as plentiful in the Great South Bay as they ever were. If we were greedy we could easily bag seventy-five broadbill, a half-dozen redhead, three or four dozen brant, and any number of coot and sheldrake in a single morning, and do this every day throughout the early spring, the autumn, and winter. Furthermore, this sort of shooting has been possible in the Great South Bay for hundreds of years, and it will continue to afford plenty of game long after we old fellows cease to give trigger."

"But, Doctor, Roosevelt adds a few words you have failed to repeat- ' hardly possible to obtain a decent day's sport 
without using a battery'; don't forget that part of it, Doctor. And that means a great deal. There was a time-and it was when the ducks and geese in the Great South Bay were not much more plentiful than they are nowadays-that one could have fine play with several species of ducks and Canada geese and brant from any point or tiny island in that grand old lagoon, but your battery business has ruined all this. Years ago the bay was alive with canvasback, but you seldom see them now. Ducks shot at from a point or island over decoys will go to other points and islands or the open water, but when shot at from a battery on their feeding-beds in open water, where they cannot understand how a man can conceal himself, they are frightened away from the locality altogether, as Roosevelt truthfully says. I will admit that the broadbill, brant, sheldrake, and scoter - "coot" as the baymen call itare as plentiful in the Great South Bay 
to-day as they were before the battery was in use, but this is on account of the constant visits of new birds, families that have probably never visited the water before. And these birds once treated to the frightful spectacle of two gunners bobbing out of the very bay itself and firing into their midst is sufficient to keep them from visiting it again. The point shooting," continued Seth, more excitedly, "in the upper waters of the Great South Bay, where batteries are forbidden, is fine to-day, but it is only a quarter of what it wouid be if batteries were abolished at all places. And they will be done away with very soon. They ruin the sport of the real sportsman and are only serviceable to a lot of fat fellows like you and Doctor Corbin, who are too lazy to point-shoot, and to the baymen who are paid to rig out for you. Do away with this slaughter and there 'll be sport and game for all of us and for our boys in years to come. Your keeping up the 


\section{The Wild-Fowlers}

cockney practice not only renders shortlived sport possible to a few greedy individuals, but it takes away sport and game from the general sportsmen of the day and ruins all prospects of a future play at wild fowl in these waters. But, as I say, I 'll go with you and I 'll enjoy the trip as well as either of you, but it 'll be my first and last experience in battery shooting, mark me. I suppose you 'll wire Doctor Corbin ?"

"I have done so already," said Doctor Bradley; " he 'll meet us to-morrow in our old corner in the Studio. You be on hand and we 'll give you a battery argument together. The idea! Us fat and lazy! I 'll tell the Doctor what you 've said, you mean cuss, and don't you dare to back water. And now good-bye, old boy. I ' $m$ off for down-town to get my ten-gauge. You'll shoot that little twelve of yours, I suppose? Good-bye; see you to-morrow."

And the old Doctor wabbled out of the 


\section{The Wild-Fowlers}

apartment on a little trot that showed more motion than speed, while Seth began to busily arrange his desk to do as his friend had requested-shut it down.

A merry trio these three men, Bradley, Fielding, and Corbin-two of them medical doctors, Dr. Bradley in New York and Dr. Corbin in Brooklyn, while Seth engaged in literary work and kept up an establishment on Broadway-his "den" he called it-that was famous as a headquarters for the shining lights of the day in the world of letters and sportsmanship.

Seth was supposed to do his writing and sketching in the den, but there seemed never to be anything going on there day or night except a constant prattle about guns, and dogs, and books, and pictures, and horses between the merriest sort of men, of all ages and character; and instead of resembling an author's den, further than to include a great skylight and innumerable pictures, rough sketches, 


\section{The Wild-Fowlers}

and books, the apartment-quite at the top of the building - was filled to its very walls with the very oddest collection of guns, bags of shot, powder cans, snipe and duck decoys, deer and bear heads, game panels and rugs, fishing-rods, shooting-coats and -caps, and the hundred-andone other devices and instruments of the field sportsman. Seth sat in the midst of the odd outfit as Little Nell's grandfather sat in the Old Curiosity Shop, and to judge by his face and general appearance one would not be long in coming to the conclusion that he was quite at home. Clothed from shoulder to knee in chestnut-colored corduroy, with heavy pigskin shoes and short leather leggings, a pair of driving gloves just peeping out of his jacket top pocket, and a rawhide dogleash and silver whistle hooked to the flap of a lower pocket, he looked the very picture of a chivalrous fieldman.

" Get ready, Don," he cried to a lively red setter as soon as he had closed his 


\section{The Wild-Fowlers}

desk, " and we 'll be off home to tell the folks about the proposed duck-shoot." The dog was up and bounding all about the room with great glee as he observed his gentle master stride toward the whiprack, for he well knew this meant that he was to have both a romp and a ride.

"But you 're not to go on the shooting trip, sir; dogs are not used in battery shooting, and if they were I'd not break you to the despicable practice. No, sir, and I 'll be very careful not to take to it myself if all Forester and Roosevelt say about the pursuit is true. Come along, old chap, away we go!"

With these last few words, expressed in a high spirit of good feeling, and with a crack of the graceful road-whip over the head of his canine companion, who well knew the action was one of play, the two went merrily from the building, Seth calling loudly to Sam, the colored porter, to be careful about locking up safely before leaving. 
Around the corner in a side street Seth supported a shelter stall and wagon space, and thither he and the dog proceeded.

"My horse! my horse!" cried Seth, looking into the stable office door, as Don went familiarly into the wagonway and plunged both forefeet into the water tub and drank freely; "my horse, but not a kingdom for it. Hello, Gray," he continued, addressing one of the firm; "still sitting 'round talking horse, eh ? They say shoemakers are out at the toes and tailors out at the knees, and I guess stablemen are just as bad, because they 're never out any place or any time. I wish I had the time you stable fellows have-I'd wear out wagons and burn powder to ten times the extent I do now. Say, do you ever drive or ride? I never knew a liveryman to do anything but sit around his office; he 's worse than a cobbler."

"And what do you shooters do besides smoke and eat and tell lies?" fairly 


\section{The Wild-Fowlers}

yelled the immaculate Gray, firmly clasping both arms of his great chair, as a halfdozen of his brother horsemen, all friends of Seth, too, roared out with laughter.

"What else but eat and tell lies ?" repeated George Wilson, one of the group. "Why, they drink! And their best man, Henry William Herbert ("Frank Forester"), says more about drinks and drinking in his books than guns and gunning."

"Yes," put in Tom Hefferman, " and it 's a wonder you shooters would n't spend a little time sitting down quietly like we do and calmly chatting to each other, affording innocent amusement and instruction."

"Instruction! O Lord! Hear himinstruction! Instruction in the art of ' laying off.' That 's all you fellows can instruct any one about. As for eating and drinking, we shooters may gormandize a little more than you office fellows, but we don't show it. You look like a 


\section{$48 \quad$ The Wild-Fowlers}

lot of hippopotami, and it 's very fortunate you don't have to do your ' instructing' on your feet, or you 'd never get through one lesson. We may eat and drink a lot, but we can walk, and we don't each of us weigh a ton and feel as though we weighed ten."

" Say, hold on there, Whipcase," scowled Tom Songster. "What about your beautiful Doctor Bradley and Doctor Corbin? They're as fat as Tom Draw."

"Well, since you mention those two little boys and old Tom Draw I 'm done; besides, my dear boy, I would n't antagonize you, for you do ride and drive once in a while, and have wind enough to stand your ground; but your half-ossified friends there," sneered Seth in such a natural way that an outsider would never have believed him in jest, " are helpless, and I' $m$ not afraid of them. They could n't run across the room without running out of breath." 


\section{The Wild-Fowlers}

" Give it to him, Tom! We 'll stand by you - ha! ha! ha!" cried the halfdozen good fellows, fairly bubbling over with delight at Tom Songster's humorous mimic anger.

"Yes, Tom," said Seth, pointing his whip straight in Songster's face to make sure of his attention to every word, " they 'll stand by you. Yes, they 'll stand by you; they will! There is n't one of the fats who can stand. They might sit by you, but they 'd never stand."

And Seth gently lashed everybody in range with the string of his whip and nimbly bounded through the saddle-room into the stable proper, and was soon driving past the office door, laughing loudly and flailing his whip at the jolly friends indoors. Don bounded up to the lips of the pony and never seemed more sprightly in his life, while the little horse plainly showed a liking for the setter equal to that of the master. 


\section{The Wild-Fowlers}

And so we leave our gallant gentleman for the day, to meet him the following afternoon with his two field companions at the Studio chop-house.

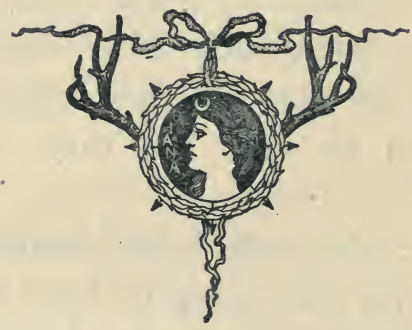

"He that takes no holiday hastens a long rest."C. S., in New York Evening Telegram. 


\section{III}

"The Quick and the Dead" 
2 


\section{III}

"The Quick and the Dead"

"Accuse not Nature, she hath done her part, Do thou but thine."

Paradise Lost.

“. . . the beadle of private life ; the beadle of our business and our bosoms."-Dickens, Dombey and Son.

PPI ERE'S the great sportsman moralist, Doctor," said Doctor Bradley to DocCorbin, as Seth Fielding strolled up to their table in the café, inquiring:

"Well, what 's before us ?"

" Hello, Seth!" cried the portly Corbin as he arose from his seat with great difficulty and yet with every indication that he was not at all displeased to do so. "I 'm right glad you 've joined us"putting forth both of his great hands" and now I'm sure we 'll have fine 


\section{The Wild-Fowlers}

sport on this trip, birds or no birds. The Doctor says you 're way up on battery shooting. I ' $m$ mighty happy ' $t$ is so, for by my true word, I know nothing about it; never saw a battery, but it must afford grand sport. The Doctor says it's real comfortable and a sure thing for ducks. Sit down, boy, sit down; waiter!"

"Yes, sir."

"We 've no time to spare. My friend will look after his own bottle; you busy yourself getting some bluepoints for him - a plenty dish-and let the broiled lobster and the green chicory for Doctor Bradley and me come at the same time. Hurry, now."

"Yes, sir."

"And, waiter!" called Bradley, " tell Martin to send out to the wagon two boxes of those dark Key Wests of mine to William. He 's to stow them in one of the leather cases or in the half-filled black rubber bag under the middle seat; he 'll know." 


\section{The Wild-Fowlers}

" I understand, sir."

" So, Doctor," said Seth to Bradley, punching his foe of yesterday sharply in his left side, " I 'm the great sportsman moralist, eh ? And I 'm way up on battery shooting, you old dog? He tells you this," - turning to Corbin, now busily employed in pouring a mug of ale into his capacious maw,-_ " does he, old manatee ? Well, he 's right; I am well up on battery shooting. At least I know more about it than he, and, like yourself, I 've never seen the machine. But as neither of you sweet little Lilliputians will be able to get more than your feet in the sink-box, I stand a good show of having plenty of experience on my initial trip. Here 's your health, noneth'less "; and Seth put away a goblet of claret and sterilaris as the waiter brought on his oysters and ale.

" Never been there?" cried Corbin. " Doctor, you lied to me! Why, Seth, he 's been sitting here a full hour, telling 


\section{$5^{6}$}

\section{The Wild-Fowlers}

me of your admiration for the sport, how you described its grandeur, and of your determination to laud it as the most chivalrous of sports with the gun."

"I never told him anything of the sort, Seth," declared Bradley; " he 's made up every word he says. Don't you let him play you, boy; the old hound!look at him give cry."

"I would n't believe either of you," responded Seth. "It 's just as Gray says - you two fellows do nothing but eat and drink and tell lies.",

"Oh, you would n't believe me, you mean cuss," responded Bradley; " then how do you like this ?-Doctor, he called you a fat, lazy pig yesterday, and said he 'd cut your company if it were n't that you were too"far gone in the matter of age and avoirdupois to take care of yourself."

"Well, I swan, Seth, if that be true it 's pretty bad, for I allus liked you. I never cussed you in my life 'cept when 
you threw the shot on my neck and Doctor here fired a gun off at the same time to make me believe I was killed outright; perhaps 't ain't true, boy, perhaps 't ain't true. But don't let me forget what that Will Gray said about us," continued the old man, making ready to do away with his share of the lobster and green chicory; " that Will Gray talkin' 'bout drinkin' an' lyin'he 's drinked more 'n all o' us, an' he 's tol' more lies than a press agent ever dreamed o' tellin'. Cuss him! I 'm half a mind to give up this trip to tell him what I think of him."

" Yes," laughed Bradley, “ I can picture you giving up a shooting trip! Seth, that 's the best thing he 's said in a week."

And so for a full two hours these good spirits chatted away in burlesque abuse of themselves and their friends, every word or two being interrupted by hearty laughter and by this one or that one of 
the jolly trio reaching to deliver a pretended blow, a pull of the coat, or some such playful manœuvre. Their table was the liveliest in the chop-house, and nearly everybody on the floor, it seemed, knew them, talked about them, and laughed when they laughed. Every now and again some friend would pass their corner, either in entering the place or leaving it, and then there would be general handshaking and much loud talking, so that the few new patrons-probably visitors to the city-scattered about, who did not know them personally, learned of them from those who enjoyed their acquaintance or knew of them by reputation.

Few men could hear and see them without feeling a desire to know them, or at least know something about them, and it was not uncommon to see waiters here and there bending over their tables, quietly enlightening their inquisitive guests. 
" The very big gentleman," one was saying to a couple at a table in an opposite corner, "that 's Doctor Corbin of Brooklyn; the other stout gentleman is Doctor Bradley, and the young man, Mr. Seth Fielding-all very old customers, sir, very old, sir. Been comin' here for years, sir; always sit in that same corner, and are never less full of fun than you see 'em at this minute, sir. Goin' shootin' or been shootin', don't know just which; but one or the other, sir, most certain."

And what a difference in the ringing atmosphere of our three friends' corner and the tables of the more quiet guestsnot many of the latter being seen, however, for the patrons of the Studio as a rule are men of good cheer, representing as they do all classes of gentle sportsmen-the yachtsman, club athlete, angler, and hunter. Still, as in all public places, the penny-grabbing, allwork-and-no-play unfortunates, with their expression of disgust at all things jovial, 
are there, washing down their mean dishes with a lightning-like speed as if the luncheon were a part of their shop duties, and when these sour-faced gentry with their ghostly conversation in full blast are seated anywhere near the cheerful class the contrast is an easy study for the poorest observer of character. They like to call themselves men of real service in the world,-these never-take-a-holiday morbids, - and look upon the lover of sport and good nature as a frivolous creature who lives long but neglects the true duties of life. But how few of the great multitude of " frivolous" beings in this world entertain the same view as these short-lived, unenlightened fools! How few of us but know that they are the real duty neglecters! We are here to enjoy the world, not suffer it. Why live a little while in misery, in preference to a long life of merrymaking ?

And let us pray the Lord that these good cheer and true health abolitionists 


\section{The Wild-Fowlers}

will be always in the minority. In what sense are their scowls and growls of service? Who is benefited by their every minute and the every minute of the poor wretches in their clutches being devoted to drudgery and health-destroying ? No one-not even themselves, nor their weakling offspring.

And the jovial man of kind heart who raises up the very victims of these sourmouths and restores broken-hearted men and their shattered homes-he is but a frivolous thing! If so, frivolousness is godliness, and let us all hope our children may be thus afflicted.

But away with all talk of the lowspirited! Our path is the path of the cheerful; so let us return to our merry trio, the fat doctors and their good friend Seth.

". . Accordingly we find that those parts of the world are the most healthy where they subsist by the chase ; and that men lived longest when their lives were employed in hunting, and when they had little food besides what they caught."-W. JonEs. 


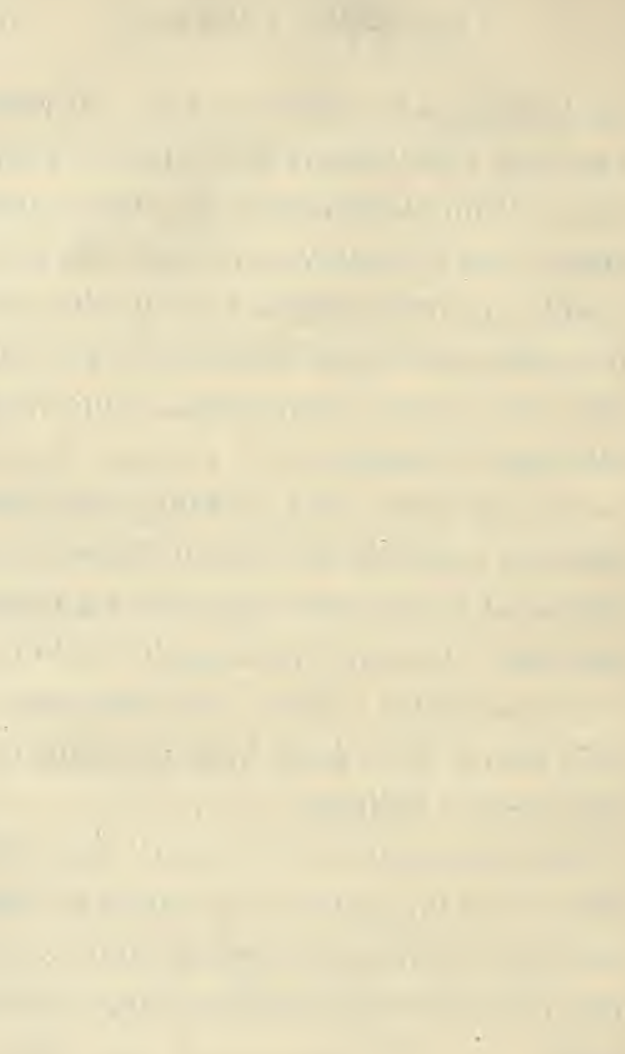




\section{IV}

The Merrick Road 


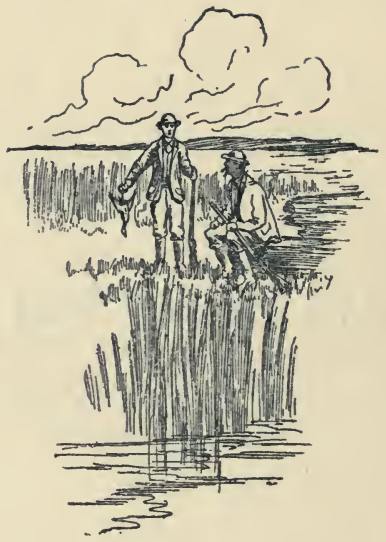




\section{IV \\ The Merrick Road}

“. . . the pleasantest converse on subjects manifold, over the composing cigar, . . . the untutored jest, the untaught laughter . . . the buoyancy of soul caught from all these things."-HENRY WiLliam HERBERT.

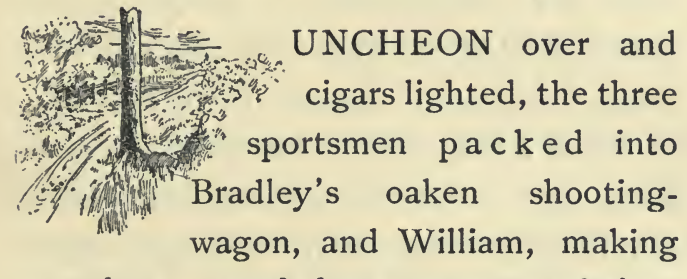
sure that none of the traps were missing, and that each gentleman had no purchases to make or any further city details to attend to, sent his team briskly down Broadway to Thirty-fourth Street and down this last thoroughfare to its very end to the ferry plying between New York and Long Island City.

"Drive right on the boat, William," 5 
shouted Seth; "we 'll not disturb these bags and boxes on both sides of the river. Besides,"-turning to Corbin,_- "Doctor, we ' $d$ miss the train if that fat Bradley had to walk ten yards with his guncase."

"Good idea, Seth," responded his friend, " and while you look to William transferring the traps to the smoking-car when we get across, I 'll attend to the tickets; Bradley, what 's the name of the station we go to-Ramseytown ?"

" No, Amityville," answered the Doctor; " get three excursion tickets; you 'll save four cents on the lot-enough to buy yourself one of those Gowanus cigars you like so well."

" I 'll buy the darned tickets one way," said the puffing Corbin; "I would n't bother taking care of the blamed return stubs if I could save four dollars."

"Why not drive all the way, Doctor?" inquired Seth of Bradley, as the wagon and its great load rolled on to the ferry- 


\section{The Wild-Fowlers}

boat, the team apparently enjoying the day as well as any of the party; "it 's only thirty miles or so, and the roads are the best in the world in any sort of weather."

"Good!" cried Corbin; " just the thing."

"Good, too," echoed Bradley, " if William has a pair of lamps and more skins for our knees than I see now. These dust wraps are as thin and cold as cheesecloth."

And William said he had the lamps, and warmer robes, too, and, handing the reins to Corbin, he stepped down and brought out from under the front seat two great buffalo skins, his master's huge cape mackintosh, and a well-worn quarter-inchthick felt ulster-"This, sir," said he, holding up the latter garment in both arms, " the madam says you wanted for the coffin boat."

"Coffin boat!-what the devil does he mean by coffin boat?" queried Corbin, 
his little black eyes shining from his fat head like two jet beads.

"The battery, of course," answered Seth for his friend; " that 's the best name for it out of all the things it 's called. Its other appellations are sinkbox, coffin box, raft boat, surface boat, marine cellar, and ducking machine."

"Then you agree to our driving ?" asked Bradley, as the ferryboat pushed its way into the dock.

"To be sure!" echoed Seth and Corbin, and William was hurried back into the wagon.

Away the spanking team went the second the ferry chains were down, Bradley holding the ribbons, while his faithful man busied himself plying the skins and great-coats about the feet and hips of Corbin, whose enormous fat seemed no protection from the chilling wind of that fine April afternoon.

The road through Long Island City was rough-cobbled, and the surrounding 


\section{The Wild-Fowlers}

country, though still showing signs of having been at one time a very paradise in its natural state, was uninviting. Seth remarked the filth on all sides of the street they drove through, and compared the dilapidated condition of that part of the town to many parts of Jersey City.

How strange, he thought, that the filthy main driveways of these two cities should be the great gateways to the most beautiful scenic spots the country boasts of-Long Island, with its Great South Bay; Greenwood Lake, with its romantic Warwick Woodlands, and the Highlands of the Hudson, walled by the far-famed Palisades.

" Wait till we get out o' town a bit, Seth," pleaded Corbin; " then you 'll see something worth looking at. This part of the Island is pretty bad, I 'll admitthe dirtiest spot this side of Little Italy on your own beloved Manhattan Isle."

"These miserable beings clustered here in this filth!" exclaimed the young 


\section{0}

\section{The Wild-Fowlers}

man. "They should be separated and forced to live just so far apart. Their squalor is the result of too great a mingling of one sort of being, the dirty class. The Board of Health or whatever body has the say should scatter them like so many, so many-well, I don't know what; no species of insect, reptile, bird, or beast, is sufficiently unclean to be mentioned in comparison. They live worse than pigs in captivity. What a lot humanity could learn in the matter of cleanliness and general comfort from even the poorest specimens of the game we sportsmen kill! And are these disease-spreading bipeds the superiors of our beautiful deer family, our cleanly feathered tribe, or my setter and my little cob?-not much! Individuals of mankind may be superior to their brothers, the so-called lower animals, but the race-never!"

"They 're too poor to keep clean," ventured Corbin.

“ No, it is n't poverty that makes them 
filthy," replied Fielding. "The lazy and filthy man always cries poverty as an excuse for his dirt and indolence. Poverty and filth need n't go hand in hand any more than riches and rottenness need unite. The laggard's poverty excuse for his foulness is an insult to everybody who can't brag of wealth. Are all poor persons dirty? No, sir, I won't stand for that. The poor as a class are just as cleanly as the rich. These whelps hereabout are just plain, downright dirty, lazy bipeds, that 's all, and they should be scattered-not allowed to fester in a mass."

"Well, don't disturb them, pray," quoth Bradley; " it is better to have a lot of rattlesnakes in one quarter than scattered all over the globe. You would n't like to see these lepers wading our clear trout brooks or running all over our beautiful quail ground and snipe meadows, would you ? Corbin," continued the Doctor, " will you have a drop of 
Canadian Club? You look cold. William, pull the cork, and Seth and I 'll take a little taste too. This wind is freshening considerably. It 'll be quite sharp in the battery at daybreak. Say, boys," here bowing a little acknowledgment to Seth for the glass handed him, " which of us go in first? Do you wish to get up at three o'clock, Doctor, and lie in the box with Seth for the morning shooting, or shall I; or shall we both take the first hours and leave Fielding aboard the sloop to talk the Captain daft ? What say you ?"

" Oh, arrange it between yourselves," responded Seth; “I care little about it. I ' $m$ merely going to step in the thing for a minute or two just for the experience. I want some point shooting at blackduck, the king of wild fowl. The Captain can put you two light weights in the coffin as early as he wishes, then get me to the bogs. If you two get in the battery together, the trays won't need any iron- 


\section{The Wild-Fowlers}

weight decoys. The box 'll sink all right without any iron. You and Corbin would look well on a red tandem bicycle, Doctor; why don't you buy one? That tricycle used by Professor George Lockhart's elephant Boney would be just the trap, if it were bolted and braced a bit extra." And here Seth and Bradley got into such a scuffling that more than once one or the other must have fallen out of the seat had Corbin or William not laid a hand on this or the other one's shoulder as a sort of support.

On rolled the merry vehicle at a firstrate speed, the Doctor's bay team gaiting it fresher at every step as it seemed, until the much-despised city district had been left far behind and a wide rural view lay on all sides and as far ahead as the eye could see.

The pretty towns of Richmond Hill, Jamaica, Springfield, Rosedale, Valley Stream, Lynbrook, Millburn, and Freeport were all journeyed through in their 
order, and many were the expressions of admiration that escaped from the alleviated Seth as he espied the various pleasing sights along the route.

" Charming!" he cried, indicating the beautiful natural panorama by a sweep of his arm. "So clean, quiet, natural, and generally inviting. My God! what a difference in this and the filth of low-lived civilization! Strange those wretches who live in hovels do not seek these rural retreats; strange, very strange-to me, at least."

"I knew you 'd like it, Seth, so I drove the longest way," said Bradley. "We 'd have gained a half-hour by another course, but the road would have been no better and the scenery less attractive. See that pond there,-Doctor, do you see it ?-a natural reservoir. There are a hundred on the Island just like it. That 's the drinking-water for the people of Brooklyn, and it 's fine, but the pipes and tanks nearer the city are so bad 


\section{The Wild-Fowlers}

that the water is rendered unfit to drink by the time it reaches the crowded districts. These ponds are n't like the made-to-order tanks we have in Central Park on Manhattan Island. These little lakes are as nature made them, and they are as clean as they are clear. No malaria or fever emanates from these beautiful waters. If the disease germ reaches the drinking-cups of the city, it comes from the rotten city pipes or the filthy town reservoirs - never from these properly cared-for waters."

"They look fine," said Seth; " as if the men who cared for them were honest and practical-not merely favored politicians, given positions whether their ability made 'em fit or unfit for the work. The condition of this drinking-water is certainly commendable," he continued, " and so is the drinking-water of New York in general. As you say, Doctor, any disease caused by this particular substance comes from the foul condition of 
old city pipes and reservoirs, but there are parts of this country where nature is imposed upon by the employment of impractical men to build and conduct the water contrivances-favored but indifferent and wholly ignorant politicians. $\mathrm{Na}$ ture is always blamed for the errors of stupid man. Now, I 'll wager I could produce half a hundred natives in any complained-of settlement who 'll make affidavit that they never knew what malaria or fever of any sort were before the politically conducted water-towers, and waterways, and water-sluices, and waterpipes, and water-mains, and water what-nots were laid out and built up. Ignorant man stagnates a spring pond or dams a tide-water, creating foul gases and unnatural quantities of constantly rotting vegetation, and then, then-he damns Nature for the ill-health that ensues from his own impracticable work. Nature 'd be all right, with lots of odds to spare, if man 'd be compelled to work with his 


\section{The Wild-Fowlers}

head as well as with his hands. The great trouble with this world is in the army of rogues and blockheads it supports. Half the men who are put to work in a collarbutton factory don't know what the collar buttons are used for, and those of this half who are not too stupid to see the advantage in learning are too lazy to learn."

"That 's right, Seth," fairly yelled Bradley, "and the men who make guncases don't know what they 're used for; if they did, they 'd put the coarse, waxend sewing of the handles where the raised-seam stitching would n't nearly cut the hand off of you when you carry them. As for drinking-water," continued the Doctor, "we 'll have no disease come from it at all in a few years, Seth, if what your friend Haerther claims is true. $\mathrm{He}$ says a Michigander has invented and patented and fully demonstrated as practical a machine that can turn any sort of liquid, from that of the ditch to the salty 
contents of the ocean, into sparkling pure water; and the same machine, he says, can make any particular sort of water, all the way from common seltzer or vichy to apollinaris. The inventor claims there is at present no absolutely pure water in the world save new rain-water fresh from the clouds and that produced by his apparatus; that most of the high-priced bottled waters are more impure than any common city drinking-water; that none of them can stand any length of time without rotting, while the new product is as good at the end of twenty years as the day it 's made."

"What makes it so pure and everlasting ?" asked Corbin.

"Why, as I understand it, the apparatus not only absolutely purifies the liquid, but also the air and the vessel used to hold the material. The machine, I am told, will remove the air from impure water, cleanse it, and then force it back in the water, which has also been 


\section{The Wild-Fowlers}

purified. The water question is the most serious of the present day. Impure water is killing thousands of people every hour. Nine cases of illness out of every ten are caused by disease-germed drinkingwater."

"I never suffered from it," said Corbin.

"Of course not," replied his brother physician; "you never drank any, but, for a man who does drink common water to say he never suffered from it is about like saying you know of a man who went to war and was n't shot. There are others. Consuming promiscuous drinking-water is quite as dangerous as going to war. Nearly every case-I might say every case-of typhoid fever comes from drinking impure water, and there are typhoid victims all over the world, and many, very many, right here in New York. Seth's friend Haerther says there are fully forty thousand fatal cases yearly in the United States. Pure water and the 
80

\section{The Wild-Fowlers}

protection of our fast-decreasing game supply are my hobbies."

"Well, you 're all right on the water question, though a little shy on water drinking," remarked Seth, " and as for protecting game the only proper way is to stop the sale of it. With no market for birds, deer, and fish, the man who slaughters in and out of season would soon give up the practice."

"I agree with you," said Corbin.

" So do I," quoth Bradley.

"The market shooter is the culprit," continued Seth; "no doubt about it. The pot hunter, the boy gunner, and the summer-vacation shooter are all slaughterers, for they kill at all seasons regardless of game laws, and the sportsman takes a lot of game too; but none of these individuals would injure the natural supply if the professional fowler were put down. He shoots wild fowl in the night, when the birds are bunched in sleep on the water with their heads under their 
wings; he uses a gun that is little less than a small cannon; he pots quail in flocks on the ground; he bags fledgling grouse that can hardly fly; he flails a net for, and uses dynamite on, brook trout; he slaughters snipe and plover in nesting time; he traps, he snares, he steals-he resorts to any method to get the goods that bring him market money-but he never makes a single move or contributes a single penny toward protecting or increasing our game. Nor do the potster, the boy gunner, and the summer-vacation fellow ever exert themselves in behalf of the very things that afford them sport. The sportsman, on the other hand, devotes both time and money to the protection of game. For every bird he bags and every fish he creels he breeds or helps to breed a dozen."

"What's this town, Doctor ?" asked Corbin, as the wagon bowled down the smooth macadam road into a little settlement quite on the edge of the salt 
meadows, and overlooking the fine bay, with the beach and sand-bars and sandhills showing with exceptional clearness five or six miles out.

" Merrick," replied Bradley; " and this is the famous Merrick Road, the popular bicycle highway. There are nearly a hundred miles of it, and it runs through the grandest natural scenic country you ever dreamed of."

"Bellmore comes next, then," said Seth, " and after that Wantah, then South Oyster Bay,-Seaford or Massapequa, as the baymen like to call it,-and then Amityville. We 'll be there before dark if the bays keep up this sort of work."

" They would go all day at this trot," said Bradley, "thanks to William's surpassing stable art-and my pocket-book. Doctor, did you ever try one of Seth's cheap cheroots? They are just the caper for out-door smoking. Give him one, Seth. The rascal uses them to tip waiters 


\section{The Wild-Fowlers}

and boatmen and hostlers with. He gave one to Tom Storms's father at Greenwood Lake 'once upon a time,' and the old man has n't been right since. We must warn Grieb if we expect any service out of him. Ah, here 's Bellmore, and there is the inn. We will pull up here, Seth, and warm Corbin with one of the landlord's milk punches. Hello, innkeeper; hello!" and all three jumped out upon the tavern's broad piazza, where the jovial landlord heartily greeted them.

Having refreshed themselves with such drinks as they each preferred-Corbin gulping two milk punches, Bradley two steaming hot-scotches, and Seth a stone mugful of new ale, while William gave his charges a sip of water and took a long pull at the very pail himself-they bustled into the wagon again and were soon chatting and laughing as loudly and merrily as ever.

Driving through the village of South Oyster Bay without a halt and out into 


\section{The Wild-Fowlers}

the fine open country beyond, the white steeple of the little church of Amityville came into view, and it was not long before the party were spinning through the very centre of the settlement.

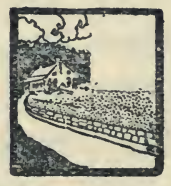

"There is a pleasure in the pathless woods, There is a rapture on the lonely shore, There is society where none intrudes."

BYRON. 


\section{V}

Cap'in Grieb, Bayman 


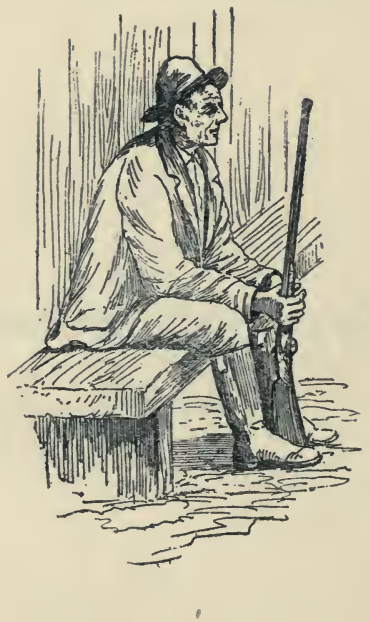

86 


\section{V \\ Cap'in Grieb, Bayman \\ “. . . wide the natural world \\ Hath welcomed him, all perfect joys to share.}

He hath no frets, he ne'er triumphant boasts."

ISAAC MCLELLAN.

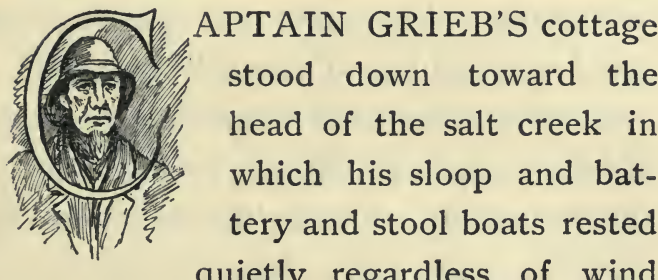
quietly regardless of wind and tide. Pulling the team up sharply at the cottage gate, Bradley despatched William to announce the arrival. The boy had not proceeded farther toward the little stoop than to the edge of the neat garden's flower-bed-where some odd lilies and a hardy pink-like flower were already in bloom-before the ruddy Captain put in an appearance. He came 
around the tiny dwelling from the rear, with both his brawny arms outstretched, striding along with his rubber-booted legs like a clumsy boy on stilts.

" Glad teh see yer, genelmen; glad teh see yer, glad teh see yer, one an' all."

" Hurrah!" chorused Seth and Corbin; " hurrah for Captain Grieb!"

" Now, genelmen," said the Captain, addressing the party, but putting his words straight to Doctor Bradley, who had gotten down and taken the bayman's hand,-_" now, genelmen, I says 't ain't no use comin' in this 'ere house cabin o' mine; 't ain't fit. Now I says we go right aboard the sloop and gets a hot meal for all.",

The suggestion seemed to strike the sportsmen most favorably, and it took but a second to arrange things to this end. Bradley and the Captain walked to the little dock, Seth drove the team there, and then all began to unload the traps, save the worthy Corbin, who 
bumped himself down upon a pile of nets and old sail-cloth with the bottle of $\mathrm{Ca}$ nadian Club in one hand and his cigarcase in the other.

"Pleasure before business on outing trips, boys. Now I says "- - here imitating the twang of the Captain to the extreme delight of Seth - "let 's drink before it gets too dark to measure; I ' $m$ careful about my liquor."

"Careful not to be without it," said Bradley, winking at the Captain.

"Oh, you mind what you say! You 're pretty near that water, and Seth and I have longed for a good chance to push you overboard. You 're no good in the world, anyway. But, say, Doctor, truth now, that was the best drive I 've had in a year, but 't were mighty cold for this time o' year in these parts-regular December wind, as sharp as icicles. What will it be to-morrow, Captain?"

"Cold an' clear fer two day at least," quickly responded the old bayman; 


\section{0}

\section{The Wild-Fowlers}

" then a warm spell, some rain, an' then cold an' clear again."

The traps were all out of the wagon now, and while Seth and the Captain stowed them away in the cozy sloop cabin, aided by the light of two round lanterns fetched from the cottage by the Captain's young son, Dr. Bradley and William arranged about the team's care, the Doctor affectionately patting the necks of his fine animals as he gave his instructions. The bays were to go to the tavern's stables for the night, then home the following day and back again the day after that, to rest another night in the tavern's stalls before carrying home their master, his friends, and the game.

"Good-bye, William," called Seth from the cabin's tiny window, as the boy wheeled the team about. "Make sure there 's no cartridges left in the wagon."

" And no bottles," yelled Corbin.

"Now, genelmen, I says we should look teh see as teh what we needs in the 


\section{The Wild-Fowlers}

way of eatables an' drinkables afore we set sail," said the Captain, when all had managed to squeeze into the little cabin. “ $\mathrm{O}$ ' cours yer hev plenty o' am'nission an' each on yer a gun, I hope."

" Well, to start with, Captain," replied Doctor Bradley, "what have you to eat and drink ?"

“ Kegs o' water jes fetched from th' spring by thet 'ere boy o' mine, all th' good coffee all on us could drink in a week, salt, pepper, eggs, pertaters, candensed milk, two bushel o' clam, a basket o' isters, fresh flounder an' eel, some fine bacon, an' a plenty o' ile, coal, kinlin, matches, an' lots o' comforters for all on us teh sleep in."

" Bully for you, Captain!" cried Seth, throwing back his head and laughing with great glee when the sturdy bayman innocently included the fuel and bedclothing with the list of food and drink.

"But, genelmen," added the Captain, "I says we must-thet ruther be yer 
must-hev somethin' else, some steak, an' tea, an' beans, an' pickles, an' cakes, an' cetlus powders, an' jam, an' whiskey, an' the tother nick-nacks city folks like teh eat."

" Good boy, Captain!" shouted Seth again, fairly convulsed with laughter at the expression of Corbin's face when he heard the bayman's new bill of fare.

"Well," said the fat man, "by my true word, Lieb-_-"

" Grieb, sir," the Captain said, modestly correcting him; " hard name teh 'member; hev teh say it forty times a hour teh new 'quaintances; 't ain't no objection though."

"Grieb, yes, to be sure. Well, Grieb, you 're a wonder, though we don't eat cetlus powders. The Doctor, here, told Mr. Fielding and me that you were a sour old duffer, and we did 'most hate to come down here at one time. Now, Doctor, you owe the Captain an apology; he 's all right, eh, Seth?" But the Captain 


\section{The Wild-Fowlers}

had had enough experience with rollicking sportsmen to see the jest in Corbin's pretended rebuke to his friend, and with a good-natured wave of his big arm he climbed out of the cabin, and called to his boy:

"Adam, you mus' go teh the stores fer th' genelmen; get a gait, now!"

"O Lord, Seth!" said the ever-prepared Corbin, down in the cabin, as he heard the Captain's command ; "O Lord! Now he 's included a gate with the other things."

" Now, boys," said Bradley, "we must stop fooling, and get what supplies we want, and then set sail. How far east shall you go, Captain ?" he added, as the bayman came astern with a keg of water.

" Off Babylon, sir; we 'll anchor on th' battry groun' teh-night. You genelmen 'll sleep in the cabin, an' my boy and me 'll bunk up for'ard in th' decoy box. There 's plenty o' coverin'. Th' battry 'll be out afore yer up, an' Adam 


\section{The Wild-Fowlers}

an' me 'll give yer a hot bre'kfas' afore yer teh rights."

Adam appearing on deck at this moment, his father turned him over to his guests, and they in turn gave him a list of the articles desired from the village stores. Nearly all the items mentioned by the Captain, and half a hundred other things, were written down on a slip of paper, and Adam was warned not to miss getting one of them lest he wished to be thrown overboard. If the steak were less than three inches thick, or the chickens not just so tender, he was to be left ashore to eat them raw, so Corbin threatened; and if the butter were poor, he yelled at the boy, it would be smeared on the mainstick, and he made to climb to the very top.

So merry were the sporting trio in the little cabin, and so good the supper given by the Captain, that the evening wore away before any of them realized it. It was ten o'clock; Adam had returned 


\section{The Wild-Fowlers}

with the shop articles to an item, and was busy clearing away the great mess of dishes and pans soiled at supper; Corbin and Bradley were all but asleep, with their cigars half down their necks; and Seth and the Captain, now firm friends, trimmed the sheets and held the tiller as they talked over the prospects of game the following day. The sloop - by name the Coot - had cleared the creek and was making east. Seth was in a joyful elevation of mind, and he more than once expressed his delight to his companion. The moon, full and silver-white, shone in the deep blue sky, and its effulgence played on the water along the very course the smart sloop was making. Fire Island Light, fairly red when shining with the silvery moon's rays, flashed out every now and again far to the east; on the bar the reflectors of the life-saving station shone clear and steady, and the village lamps on the mainland burned as brightly as if only a few hundred yards away. 
96 The Wild-Fowlers

"Adam," whispered the father, an hour later and still at the tiller, "be all the genelmen asleep ?"

"Yes, dad, all of um," the boy softly replied.

"Then we 'll turn in, too, fer here 's where we put th' hook over."

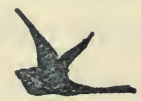

"Sometimes I go a-fishing and shooting, and even then I carry a note book that, if I lose game, I may at least bring home some of my pleasant thoughts."

Pliny. 
VI

" Rocked in the Cradle of the Deep " 


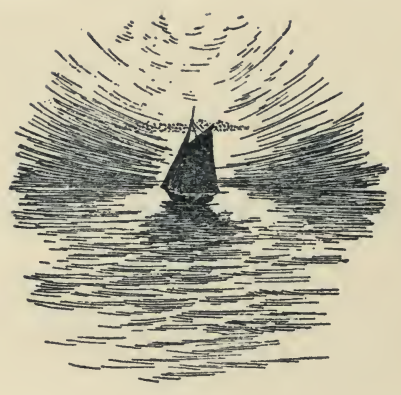

98 


\section{VI}

" Rocked in the Cradle of the Deep"

“. . . the sleep under the blue vault of the skies, sweeter and sounder, lighter and more luxurious than princes catch on beds of eider-down and velvet."

Henry William Herbert.

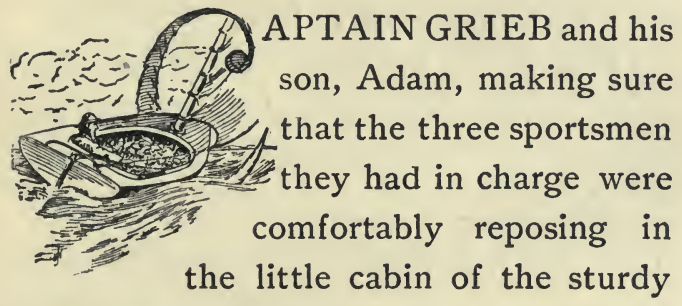
sloop, arranged things to a nicety on deck, then stealthily made their way forward to the decoy hole where they intended rolling themselves up in blankets for the night.

" Lor', Adam," said the father, " thar be thos' barols o' water, th' exter brant stool, th' boxes yer fetched from th' 
stores, an' th' single battry, all with th' reg'lar stool-no room lef' fer us teh turn in. We 'll hev teh bunk with th' genelmen; too col' teh sleep out o' cuver intire."

"You go in the cabin, dad," said the boy. " I 'll sleep here; I 'd ruther."

"So be it, so be it, son, but cuver up well; it 's frosty; put th' tar-poleans under yer, an' one on 'em over yer; we 'll put out at four. Good night, lad."

The boy had his shoes off and his head under cover almost before his parent reached the little cabin hold, and the Captain himself was soon snugly blanketed and comforted and pillowed close astarboard on the very bottom board of the sloop, but quite in range with the three other cabin occupants, Seth and the two doctors, who were sprawled out at full length on the well-covered cabin bottom, each apparently enjoying sound slumber.

"All turn!" cried Seth, as the Captain 


\section{The Wild-Fowlers Ior}

wormed himself in line, and then Seth and Doctor Bradley instantly engaged in uproarious laughter, as the fat Corbin, suddenly awakened at Seth's sharp command, and the Captain's wedging into line, thunderingly growled dissatisfaction at being " in the company of two idiots who did n't know when to quit," as he put it, and then turned over on his side with the clumsiness of a manatee and in the space a young elephant would require, and instantly took up snoring again as though he had never been disturbed in his life, his two companions the while squeezed into such small quarters by the fat man's manœuvre as to make them laugh all the more.

"Listen to the steam organ!" said Seth aloud, as Corbin's sonorous breathing continued with increased power.

"More like the wail of a drowning sow," ventured Bradley, in a whisper, and fairly convulsed at the unheard-of nasal grunting of his sleeping friend. 
"Wonderfully considerate of the comfort of others; takes up such a little amount of space," said Seth, louder than ever. And here the Captain, who, fearing any acquiescence on his part would urge the two jokers to increased hilarity, was trying his best to make believe he wholly disapproved of what was transpiring among his guests, but was plainly heard to mutter a little muffled chuckle and then smother his head in the hunting-coat pillow.

It was truly the most extraordinary snoring Seth had ever heard, and he remarked this to Doctor Bradley. Then Doctor Bradley told Seth that it was the loudest snoring he had ever heard; then they expressed the same conclusion a halfdozen times in chorus, and so kept up the subject between them, sandwiching the remarks about the exceptional vocal qualities of the fat man's nasal organ with a variety of ludicrous imitations of the vulgar sounds, until the Captain's restlessness 


\section{The Wild-Fowlers}

showed itself plainly and calmed them down. It would n't do to make the old skipper real angry, Bradley argued in an undertone, and the two good spirits, who could n't for the life of them go to sleep, reduced the pitch of their voices and rattled off short speeches on half a hundred subjects.

But Seth could n't resist the temptation to jest. The hour and conditions prevailed upon him.

"Mighty dangerous this lying out here in deep, open water in a sloop without any sort of outside light aboard," said he to Bradley, not long after his friend's quieting word; " and what a wind is springing up! A nor'wester strong enough to lift us up and clean over the outer bar!"

"Think so?" quoth Bradley.

" Undoubtedly," answered Seth; " it would soon carry us out to sea if our anchor chain gave way and an outlet were hard by. We 're drifting now and 
I04 The Wild-Fowlers

pounding against some big rocks-feel that?"

The wind certainly blew a gale, and the boat rocked violently and seemed to be bumping heavily; but no danger lurked in the Coot's midnight harbor, and no one knew this better than Seth himself, the merry rascal.

" By ginger! I don't like this carelessness," responded Bradley, fairly alarmed; " no light on deck, high wind, dark night, deep part of the bay, open water, rocks, indifferent persons aboard and a cranky anchor-Captain! Captain!" and Bradley pulled wildly at the comforters and blankets, aiding his cries to awaken the old bayman, while Seth, conscious of having roguishly evoked unnecessary fear on the part of his friend, and anticipating a humorous state of affairs when the Captain awoke to the situation, roared up his sleeve.

"Now I says, genelmen, as yer should close haul, ef yer' spect teh be awake 


\section{The Wild-Fowlers}

when th' sport be on teh-morrow; yer 'll 'quire sharp eyes an' quick hands in th' battry, genelmen, an' yer 'd bes' get some sleep."

"Yes, shut your mouths, at least, if you can't close your eyes," put in poor Corbin, as he turned over again and took every speck of bed-covering with him; “ put 'em out o' the cabin, Captain, so we decent fellers can sleep. Seth, you 're a little loafer, and that old nighthawk chuckling and whining alternately beside you there should be ashamed of himself. He acts as though he never slept away from home before. When he is n't an ass he 's a coward. Shut up, both of you!" and the fat man's tone of voice clearly indicated anger. The naturally good-natured old fellow could n't bear being everlastingly disturbed in his slumber.

"I can't sleep in unsafe quarters," responded Bradley. "You fill up with drink and food until you 're drowsy 
enough to snore anywhere, regardless of conditions. Captain," continued the Doctor quite seriously, "Mr. Fielding says there 's no light on deck, that we 're in deep, open water, near an outlet and on some rocks and likely to be smashed to pieces if not blown out to sea-hear that wind! The sloop 'll blow over in a minute if the anchor chain does n't give way! My, what are we bumping against ! Had n't we better do something ?" and the Doctor, now fairly angry as well as frightened, reached over and gave Corbin a sound drubbing on his fat shoulders. " Confound your lazy indifference!" said he; " it 's such as you that cause mishaps on the water. Captain, what 'll we do ?" “'Well, I says as yer 'd bes' go teh sleep ef yer' spect teh get eny birds in th' mornin'."

"But what about this wind and these rocks ?"

“'Lor', Doctor, Mister Fieldin' be a jokin' ef yer-it 's low tide, thar beant 


\section{The Wild-Fowlers}

more 'n tew foot o' water fer a mile about, an' not a piece ef rock big 's a clamshell in th' hull bay. We 're in th' eel grass, an' th' bumpin' be nuthin' et all 'cept th' hook rope a-pullin' tight an' th' tiller pin a-shiftin' teh th' swell unct in a while. Go teh sleep, genelmen; yer 'll be glad on it teh-morrow."

"Oh, I know all about the bay and the tide and the, the-Seth's rocks," said Doctor Bradley, somewhat comforted by the practical man's making little of the situation; " he can't fool me, he is n't trying to fool me-hear that wind! Can't we put a light on deck ?"

" Oh, genelmen, don't fret so; thar be no danger; no sloops is in th' bay tehnight 'cept our own an' Purdy's, an' th' win' beant over warm; don't fret so; go teh sleep; birds is plenty; go teh sleep; I ain't follered the bay fer fifty year fer not teh know th' danger times; go teh sleep; birds is plenty."

"All right, Captain," responded Seth, 
not wishing to try the old fellow's good nature too far; " good-night. Come on, Doctor Bradley, everything 's safe; I was merely testing the heeding qualities of that hopeless man, Corbin - good-night, everybody."

"Well, I 'm with you," said Bradley, resignedly, but none the less disturbed by the awful gale and the booming of the tiller post and anchor rope, " if that inconsiderate beast's grunting does n't keep us up all night. Good night, Captain; good night, Seth; good night, wild boar, and mind you now, Corbin, I 'll not suffer your snoring from now on. I 'll trust to the Captain's word about our safety in this hurricane, but not one bar of your nose solo will be allowed. Talk about putting us out of the cabin for merely being careful, you indifferent old broadbill! Just snore once more, and I 'll show you who 'll go out of the cabin. Good-night, Seth ; good-night, Captain."

" Good-night, genelmen." 


\section{The Wild-Fowlers}

But Doctor Corbin, the dear old chap, did snore, and louder than ever, but he was n't put out of the cabin as threatened, for none of his companion sleepers heard him. Their long day of good merriment outdoors told gently upon them at last, and they were rocked into that sleep known only to those made tired by natural exercise and good nature.

The Captain never moved from the moment he settled down after quieting his noisy guests, and was not even heard to breathe. He was soundly asleep the minute he first settled himself comfortably under the covers before Seth began his yarn of possible shipwreck, and probably would not have awakened until arising time in the early morning had not the fretful Bradley aroused him.

Little Adam lay snugly among the tarpaulins in the decoy hole, with the bright stars shining down full upon him, and the soft, salty spray, made by the gale-driven low-tide water breaking o'er the smart 
sloop's sides, playing gently about his shaggy head.

There was something soothing in all this wild play of the elements, even to the timid Bradley; there is always a comforting susceptibility during repose upon the water aboard a sturdy craft in a safe anchorage, and the wilder the wind and wave, the greater the toss of the Captain's Coot, the sounder seemed the sleep of the sporting trio and their skipper.

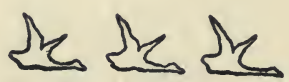

"To him who in the love of nature holds

Communion with her visible forms, she speaks

A various language; for his gayer hours, She has a voice of gladness, and a smile, And eloquence of beauty, and she glides Into his darker musings with a mild And healing sympathy, that steals away Their sharpness ere he is aware." 


\section{VII}

Seth Fielding's First Lesson in Battery Shooting 


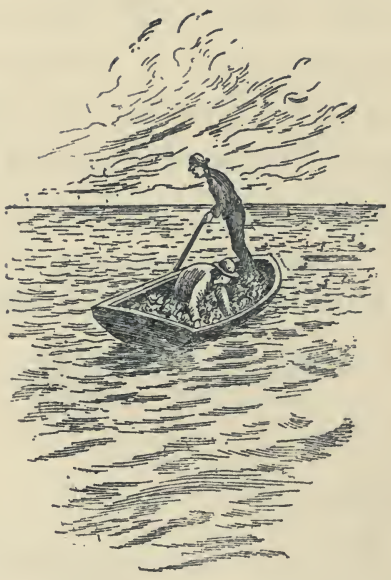




\section{VII}

\section{Seth Fielding's First Lesson in Battery Shooting}

"The fowler ever finds some new delight,

Amid the varied scenes that nature spreads ;

Far from the tumults and the clash of life,

Thro' all her loveliest haunts, rejoiced he treads. Oft where the breezy bay outspreads its sheet

He lurks in ambush 'mid the russet reeds, Or from the floating battery stealth'ly peers

To mark the shallows where the bluebill feeds." Haunts of Wild Game.

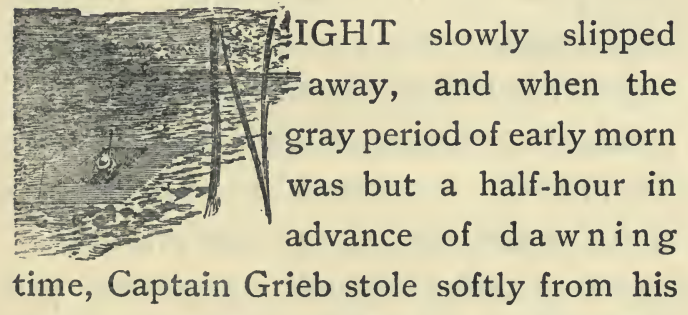
cabin couch toward the heap of tarpaulins, intent upon rousing little Adam, his youthful helpmate; but ere the old man had gone forward farther than the first 


\section{4 The Wild-Fowlers}

tiny porthole of the sloop his quick eyes discerned the faint outlines of the boy, already thoroughly awake and busy tying on his clumsy shoes.

No greeting passed between them; no word or signal marred their sharp movements. A mere glance at each other, a single meeting of the eyes, conveyed the mutual acknowledgment of the new day.

The man hoisted an oaken pail of salt water aboard, plunged both his hands and half his head into it, splashed and spluttered in it a full minute, rubbed his eyes and great mass of hair with a violence that would have jarred up a hundred headaches in the cranium of a less hardy person, wiped himself with equal ferocity for fully five minutes on a coarse red-bordered towel, tossed the latter article to the boy, emptied and refilled the pail with the dash of an athlete, and then actually hornpiped himself astern and bumped down upon the cabin corner like a gleeful boy of ten, rapidly beating his 
legs the while with his great palms, and most humorously humming a sailorman's tune precisely as we imagined Mr. Peggoty humming to himself on the beach of old Yarmouth.

No sign of the dawn as yet appeared beyond that peculiar dusky gray of early morn, but the old Captain's squinting sweep of the horizon told him the weather prospects were fair, that the approaching day promised at least clearness and sunshine with a cold, brisk northwest wind, the very next best sort of conditions to real good ducking weather. Not the sort of weather for great flights, thought he, but perhaps no better day on earth to answer the purpose of the three rollicking sportsmen he had aboard.

The wind still swept spankingly from the northwest, though milder, much, since midnight, and the stars twinkled and the lights of the mainland and the life-saving stations on the outer bar were still shining forth as merrily as 
ever. Fire Island Light, now but a few miles to the east, shone with regular flashes ten times more distinct than when viewed from the creek mouth at Amityville, and the boom of the rolling surf came rumbling faintly from the south, like the muffled noise of distant thunder.

A few minutes later the Captain had brought the dingy and stool boat from the stern to the port side of the Coot, and, with Adam's assistance, was lowering the single ducking battery from the top of the decoy hole to the choppy water's surface.

Little bunches of broadbill were flitting by in the gray light, now winging swiftly seaward across the bows, again whistling along westward or eastward, off port or starboard, and sometimes scurrying quite overhead in all directions.

Brant, too, in numberless platoons, were flying by, while thousands upon thousands floated on the water on all sides.

Flights of black scoter ("coot") that 


\section{The Wild-Fowlers}

looked for all the world like lazy brant, reeled along the very surface of the great lagoon, and a wedge of big Canada geese came

“Straight o'er Jersey's sandy borders, O'er Long Island's sea-like sound, Past Fire Island, bleak Montauk,

North, still north, unerring bound."

The single battery having been successfully righted, the Captain entered the dingy, made fast the battery's tow-line to the stern of the stool boat, and the latter craft's line to the stern of the little dingy, and, plying the oars, pulled away to the battery ground, two hundred yards south of the sloop's anchorage. The water was low, but the tide was slowly running in upon the shallow beds of eel grass. A hundred yards nearer the Captain and his rigging the Coot would have been well aground in any sort of tide.

Delicious fumes of fresh, boiling coffee, toasting biscuit, and frying bacon permeated the crisp air, and little Adam looked 


\section{8 The Wild-Fowlers}

the very picture of a sailor cook as he stood butter-knife in hand and aproned to his very feet in the cabinway, calling to his father:

" Com' in, dad; th' bre'kfas' be ready, an' th' genelmens is up."

And they were washed and combed and dressed, too-each of them in true ducking apparel, the doctors both in rubber boots, gray canvas coats, and corduroy caps and trousers, and Seth snugly arrayed in high, heavy tan shoes, a grayish dog-skin jacket, a woollen pull-down headgear of the same shade, and rubber, silk-lined gloves.

Gray is the correct color for battery work, just as light brown or dead-grass shade is the proper thing for full-season upland shooting, or in the late autumn play in the brown marshes for jack snipe and in the salt-meadow blind and sandbar pit for bay birds, and no one knew these important details better than our three good friends aboard the Coot. 


\section{The Wild-Fowlers}

"Come in, Captain," called Seth; "you 're to have the biggest slice of bacon and the hottest cup of coffee for beating us out of bed."

" He 'll take rum afore his coffee, or by my true word I 've judged him too wise," said Corbin, flask and cup in hand. "Come in, man, come in! I 'm well nigh dead o' hunger, and this boy of yours here has all but asphyxiated me with bacon smoke. Come in, will you ?"

" I 'm a-comin' teh unct," yelled the Captain, firing out decoys all about him; “' hev only a pair more o' brant stool an' a broadbill er two teh toss over; can't yer wait a minute more, fer th' Lor's sake ?'

And here the big bayman reached out with an oar, and catching a turned-upsidedown decoy by its weight string, flung it up in the air and away off over the heads of all the other bobbing stool into open water, where it came down and righted itself, as much like a living duck as the brightest broadbill in the bay. 
"I 'm comin' now, genelmen," he said; and forthwith began poling the dingy sloopward, while each of his guests eagerly sought the port side to give him a hand.

" Good mornin', genelmen; th' best o' th' day teh yer, all on yer, one an' all, says I, Capem Grieb."

Seth reached out and pulled him aboard the Coot, and Doctor Bradley whipped the dingy anchor rope, very sailorlike, as he thought, to the tiller post, while the fat Corbin affectionately poked the rum flask under the bayman's nose with one hand and slapped him soundly on the shoulders with the other.

"No licker now fer Capem Grieb, says I," quoth the bayman to Corbin, waving him off; " I never drinks th' stuff afore bre'kfas', nor eny meal 'cept bedtime."

"Nor does anybody else, Captain," said Seth, slyly winking, " except an old stickler who can't go more than snoring time without his grog. Drink the rum 
yourself, porpoise; we 'll not join you. We want to see the birds we shoot at today. Come, Adam, lay on your hot biscuit and eggs and bacon, and Doctor," to Bradley,- " you pou: out that most delicious coffee. I 'll serve the food, and the Captain shall do nothing but warm up and eat."

"Oh, Lord, Captain Grieb!" cried poor Corbin; " hear 'em now-they 'll not join me in the rum! No wonderthey drank double their share afore I was up, I swear it; and your boy will tell you so, too; he saw 'em as well as I. Darn your false temperance, you two-darn your sly gulping! Darn your every thought! I 'd a sight rather be a soakthough, by my true word, I 'm not-than be a drinker on the sly, and a liar, too. Oh, Captain, don't believe 'em. I drink but little, and that in the open, but these two are the real soaking kind; they drink when no one 's looking."

And Corbin's little eyes sparkled like 


\section{I22 The Wild-Fowlers}

the beady optics of a rattler and his fat cheeks flushed with good-humored excitement as he back-handed Seth in the ribs and shied his own portly sides down into the little cabin, where now, in place of quilts and blankets and shooting-coats and-boots, among which our merry friends had spent the night, the cozy space beamed in all the glory of a real breakfast table, tiny as it was, with hot and glistening white plates, large round coffee mugs, pans brimful of steaming biscuit, platters of the thinnest brown bacon, and square dishes of golden yellow eggs.

Breakfast over, the sportsmen hastened on deck, Seth to be taken to the battery first as agreed upon, and his two friends to see him off and settled in the box; Bradley explaining as he emerged from the cabin that next to good actual sport is witnessing others in the play.

"Now I says," remarked the Captain to Seth, as he helped his young charge into the dingy, " es how 't would be teh 


\section{The Wild-Fowlers}

yer good, since yer 've never been in th' sink-box, teh not git on yer topmast when I takes it on m'self teh righten yer a bit 'bout th' thing. Some city fellers comes down here an' haint square 'nough like yer be to afess thet they haint shooted from a machine, an' thems th' kind o' men es I likes teh hev fail teh see haf th' birds es comes along an' amiss th' tother half es they do sees. Yer square 'bout th' thing, an' I says I 'd right well alike teh see yer git a nice mess o' birds, brants an' broadbills in 'ticular."

And the dingy slowly moved off toward the battery and its great flock of imitative wild fowl.

" Thank you, Captain," responded the young man. "I freely tell you I have never shot from a battery, nor have I even ever seen one before this day. I 'll gladly follow all your advice and thoroughly appreciate all you do and say in my behalf.'

“Well, then, Mr. Fieldin', when I gits 


\section{I24 The Wild-Fowlers}

yer in th' machine yer teh lay flat on yer back with yer head by the anchor end on th' little air pillar, but low down, and yer feets straight out close up agin th' big weight at th' tother end. Don' show yerself, on'y w'en yer raise teh a settin' persition teh shoot, an' don' rise up till yer well see th' full eyes o' th' birds. Haf th' men es gits in th' machine firs' rises up all-firen too soon, afore th' birds ere within two hundred yards. Th' lin' o' sight on th' water be awful deceivin'makes th' birds look three times es near es they really be. Jes yer lay right down an' keep calm; hev yer gun over yer feet with th' barrels a restin' 'bout over yer lef' ankle, an' th' muzzle ends fer certain sure a stickin' clean out o' range o' th' sides o' th' box, les yer gun goes off acciden' an' blows a hole es big es yer neck in th' sides er the bottom, which I says is more ' $n$ likely teh sink th' machine, and while yer 'd suffer no more 'n a good wettin'-es there beant enough water 
here to drown a man-th' acciden' 'd end th' day's fun, fer-So, so! Git down, Mister Fieldin'! There be two brents a-comin' straight along, an' it 's a more 'n likely es they won't see us in this gray light afore they be well up-git close down, mebbe yer can hit one-be yer loaded ? Nope, their eyes be too good; they hev turned an' won't com' aroun' again a little bit now. Ef yer hed a-bin. in th' box, yer might hev got thet leader bird; but never mind, yer 'll git a share o' good sport afore yer long in th' machine."

Here the dingy's side touched the folded canvas stretcher of the battery, and the Captain told Seth to step lightly with the right foot into the very centre of the zincked box, balance carefully, and then draw the other foot in. This the young man did as nicely as the bayman could have wished, and the old fellow acknowledged as much.

" Now, sir," said Grieb, " take yer box 


\section{26 The Wild-Fowlers}

o' cartridges, put 'em at yer feet, an' then lay down as close es yer can. Ef any birds com' along a great way off an' don' see yer, raise yer leg up like this" -and the Captain threw his rubber-booted leg up in the air and waved it up and down in imitation of a duck raising itself out of water and shaking its feathers, as he explained-“"an' quack a little like this." And here he made the oddest sort of imitative duck call ever heard in the Great South Bay.

“ Ef they be in perty nigh, an' yet not noticin' th' stools, make yer han's go pas' each other fas' like I be a-doin'. But don' show yer head an' don' smoke. Yer hev nothin' teh fear; th' machine can't blow erway, it can't sink more 'n two feet, an' droundenin' be out o' th' question. Ef th' water splashes in on yer, turn up them ere lead string pieces es runs all 'bout. When yer kills a bird, wave yer cap. I 'll look toward yer from th' sloop every time I hears yer gun-there comes a bunch o' 


\section{The Wild-Fowlers}

broadbill teh th' east'ard, git down closelike, now!"

And the Captain shoved away from the battery.

" Don't catch cold, Seth!" yelled Corbin from the deck of the Coot, where he looked the picture of comfort as he puffed on his black cigar.

"Don't shoot all the decoys to pieces, for the Doctor and I want a few for our turn," called Bradley, as he, too, puffed out the blue smoke of his first Key West of the morning.

Seth laughed at these playful remarks from his two good friends, but made no retort, being too eager to follow every turn of the flock of ducks the Captain had called his attention to.

Grieb poled to the sloop, hastily fastened the dingy astern, and jumped aboard beside the tiller. Adam, whom the father by some mysterious means signalled to, had the anchor up on the bows, and the craft made away so'west in such short 
order that Doctor Bradley and Doctor Corbin stared with amazement.

The flock of broadbill, perhaps ten birds in all, came nearer and nearer, and from mere specks in the distance slowly but gradually developed into larger objects, until, with rapid beatings of their swift wings, they came so near that the meanest eye might have made them out wild fowl. One short turn would wheel them forty yards from the trailers in the decoy fleet, and - ah, they wheel!" boom!" - a leader collapses in midair; " boom!" a second bird trails down within seventy yards of the head-line of the stool. Seth Fielding makes his first kill-a double, too-from the battery, and that with his first discharges.

No need of waving the cap, thought the shooter; every man aboard the sloop must have seen the fowl tumble in the air, for the Coot was not more than three hundred yards away, and even so soon as Seth glanced toward her after he had re- 


\section{The Wild-Fowlers}

loaded she had come about and was almost stationary, with her homely mainsail shaking in the breeze. The dead fowl drifted in the tideway toward the dingy, which Adam propelled away from the sloop a few minutes later, and were gathered in by the boy.

This sort of play was repeated many times during the morning, Seth bagging at least a specimen or two of every species that frequents the bay at this time of year. Broadbill, brant, " coot," old squaw, and sheldrake all came his way, and when he and his friends sorted the game aboard the sloop they found in the mess, besides the half-dozen broadbill and three brant, a pair of redhead, a single canvasback, and two couple and a half of grayduck.

"Hunting is the noblest exercise, Makes men laborious, active, wise ; Brings health, and doth the spirits delight. It helps the hearing and the sight ; It teacheth arts that cannot slip The memory, good horsemanship, Search, sharpness and defense, And chaseth all ill habits hence." 



\section{VIII}

The Bayman's Choice 


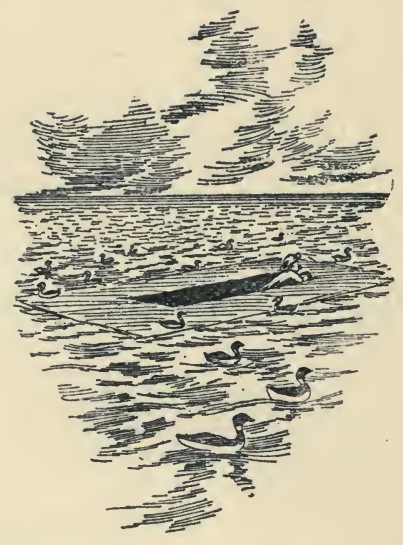




\section{VIII}

\section{The Bayman's Choice}

"For each young sportsman he hath gracious mood, Teaching him lessons of the bay and wood; Perfect in health and joyous in his ways, He cheers with sunny speech inclement days ; Hath ever kindliest word and helping hand, A cheerful nature to dispel life's gloom, And so his name and memory will survive On earth, tho' he be resting in the tomb."

MCLELLAN.

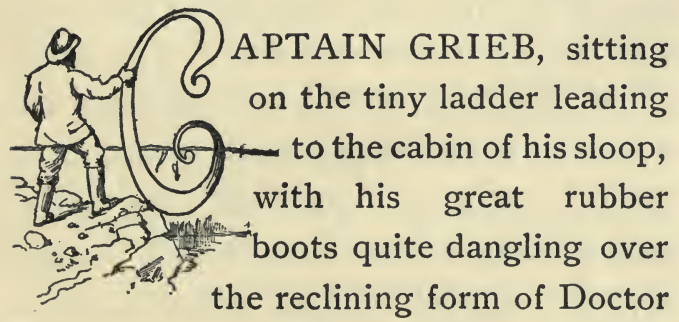
Corbin, expressed his admiration of Seth Fielding's crack shooting in the battery during the morning, and conceded to Doctor Bradley in a most humorous whisper, strangely louder than his ordinary 


\section{I34 The Wild-Fowlers}

voice, that " 'T was mighty hones' like in th' young man teh afess he hed n't shooted from th' machine afore."

It was evident that Seth had won the old bayman completely. " He 's got a bad eye fer ducks an' ken shoot better 'n eny o' them braggin' sort o' fellers es comes out here gunnin' in th' Great South Bay unct in a while," said the old man, levelling his glass once more in the direction of Seth and the battery.

' 'He be th' kind o' man I likes-a true spor'sman from th' word go. He 'd be this 'ere much ef he could n't es much es hit stool birds. 'T ain't ne'ssary teh kill teh be th' right sort enyway. I knows a plenty o' good an' true spor'smen es could n't hit a hull bunch o' stool ten feet erway. I likes a spor'sman in eny shape-good shot or not-but I kent stan' th' pretender man, an' I ken pick out th' spor'sman from th' pretender feller et a glance. I 'm a-down on th' feller es tries teh deceive me. I beant 


\section{The Wild-Fowlers}

'tickler es teh who I takes in th' bay, so long es they don't preten'. I 'm jes' es satisfied with a greenhorn es a right smart crack shot, but I kent stan' th' knownothin' feller a-tryin' teh make me think he 's all-firin' edecated 'bout shootin' an' fishin'. I 'll treat a man es don' know a gun from a clam rake jes' es square es I treats th' 'sper'enced man, but in a differen' way, an' it 's th' bes' fer all concern'. I kent make up win' er down win' wi' a feller es tries teh swindle me 'bout knowin' things. Thar beant no shame in ig'rance enyway, an' I kent see sense in dece'vin' yer frien's, w'en by jes' sayin' yer don' know an' yer 'd like teh know yeh'd gain some'in'-I likes teh 'commodate a hones' man-w'en by a-lyin' yer on'y makes trouble. 'T ain' suppose I' $d$ be able teh run a locomotive er figger up books like city fellers, an' where 's th' harm in a-fessin' this ? Why should ig'rant men come out 'ere an' preten' teh know all 'bout th' natur' ef 


\section{I36 The Wild-Fowlers}

th' hull bay an' all 'bout guns an' rods an' th' fish an' th' birds an' am'nision, w'en they by certain don' know which en' th' shot comes out o' th' shell ?"

"I guess you are n't bothered much in this respect, Captain," said Doctor Bradley. "You don't often have these blockheads to contend with."

"Why, I does, Dr. Bradley, es sure es I 'm a-tellin' ye; but I makes it a good rule teh take care es not teh be troubled a secon' time by th' same feller. By Lor' they be th' worstes' fools es ever yer seed, an' no bayman ever helps 'em learn, w'en, if they wer a hones' sort we 'd show 'em th' same service es we give th' bes' 'sper'enced man. No, no," continued the old man with a great earnestness, " I don' want enythin' teh do wi' th' pretender chap, though ther' beant enythin' I would n't do fer th' hones' greenhorn. I beant supercisious ef enythin' 'cept th' pretender feller. I beant erfraid o' th' number thirteen, er a-doin' 
things on a Friday er walkin' under a yeller ladder on Wednesday, but I jes' wan' teh keep clear o' th' make-believe spor'sman es I would o' a red snake on th' san' beach or a rattler in th' bush. Th' right stuff beant in 'em, an' no man ken put it in 'em."

"Well, by my true word, WeibGrieb," said Doctor Corbin, correcting his confusion in the bayman's name, " you 're a rare philosopher."

"No, no, Doctor Corbin, I ain't on'y jes' a plain follower o' th' bay; but I s'pose I hev my likes an' unlikes jes' likes t'other folks, but all th' other men down here feels th' same way. How 'd this here Mister Fieldin' larn so much 'bout th' machine an' th' hull bay ef he hain't been in th' box afore? I never seed another man es knowed es much 'bout birds an' gunnin' es him. He tol' me more 'n I ever knowed afore w'en we was a-sittin' on deck las' night not a-braggin' like, genelmen-no, no, 


\section{38 The Wild-Fowlers}

-but jes' good plain reg'lar infermasion."

"Oh, Seth 's a great boy, Captain," replied Bradley; he was born with a shotgun in his hands, you might say. His father taught him chivalrous sportsmanship in his childhood, and all his ancestors were genuine sportsmen - the real kind, you know. Seth's father used to say, 'The sportsman, like the poet, is born, not made,' and I guess it 's true. The old man-an Englishman of the old school, the Johnny Bull sort, not of the conceited assinine class our young dudes so love to ape, but the genuine English gentleman, him of the glowing face, strong arm, honest heart, and brave spirit -was a great character, like his son." “Wal, I don' know 'bout th' father," responded the bayman, but his boy be a ten-poun' surf runner ef ever there be one. I wish I was his father, I wish my Adam 'd be like Mr. Fieldin' w'en he 's growed up, but thet could n't heppen; 


\section{The Wild-Fowlers}

thet ain't teh be; my boy beant edecated further 'n follerin' th' bay."

The Captain then related his experience with Seth the previous night as the two sat at the tiller in the moonlight.

" He tol' me es how he was a-goin' teh shoot No. 8 shot et th' ducks instead of No. 4 or No. 5, es be reg'lar. He said es how I war n't teh tell yer until he was in th' battery, es he 'lowed yer 'd laf et him. By thunder, he be right 'bout th' thing, tho' I mus' afess I thought him wrong et th' time he told me. He sed No. 4 and No. 5 was too big fer broadbills an' th' tother ducks, but alright fer the brents an' th' big Kenedy geese. Mister Fieldin' seems to kill alright wi' th' little No. 8 charge though, and his frien', Mr. Loomis, never uses eny shot larger 'n No. 8 on broadbills, an', genelmen, Mr. Loomis-know him, Burton Loomis, city man ?-he be a reg'lar bay shot an' no mistake. I never seed enyone es could 
I40 The Wild-Fowlers

beat him duck or snipe or plover shootin', 'tic'larly on broadbills in th' machine."

"What's your favorite load for snipe and plover, Captain ?" asked Doctor Bradley.

“ No. 8 fer kerlew an' willet, No. Io fer th' yeller-legs, both large an' small, an' th' black breas' an' golden plover, an' No. I2 fer th' surf snipe, ringnecks, dowitch, oxeyes, an' all the little snipe."

"And for the ducks and geese, what do you use ?" asked Doctor Corbin.

“No. 4 fer th' ducks, all on 'em, an' double $\mathrm{B}$ fer the brents and Kenedys, tho' I think wi' Mr. Fieldin', No. 4 would do alright fer the brents."

"Suppose you had a choice of but onesize shot for all the bay birds and one for all the ducks and geese, what would it be ?" from Bradley.

“ Wal, I 'd take No. Io fer all th' bay birds-th' snipes and plovers-and No. 4 fer th' ducks an' geese."

"Many canvasback and redhead come 


\section{The Wild-Fowlers}

in the Great South Bay nowadays, Captain ?" asked Corbin.

"Unct in a while; they beant all gone never teh return, es I 've heard it sed by som' folks. Las' fall I seed a-plenty o' canvasbacks, redhead, an' grayduck es well es swarms o' all th' common birds - broadbills, ol' squaws, brents, blackducks, sheldrakes, an' th' coots. Teal don' reg'lar come in th' bay et eny season, but we see 'em in th' fresh ponds of'en, both th' greenwing an' th' bluewing, tho' th' beautiful little greenwing which be no bigger 'n a goodsized pigeon be scarcer ' $n$ the bluewing, which be a flock bird, while th' greenwing be mos'ly seen in pairs. Yer frien', Mr. Fieldin', genelmen, he knows all 'bout these things, es I larned las' night. $\mathrm{He}$ did n't tell 'em teh me right out like, feelin' perhaps es how I orter know es much es he 'bout th' bay. He sort o' asked me ef this an' thet worent th' case, perlite like, yer know." 
"What do these ducks feed on, Captain ?" asked Doctor Bradley.

“Wal, I s'pose season hes a good deal teh do wi' it, es wi' us folks, but th' broadbill, which es our plentiest bird an' which I likes teh eat better'n redhead an' pretty near es well es canvasback, feeds a little on grasses an' mostly on little clams an' little mussels no bigger 'n yer littlest fingernail. He dives fer his food, pulls up the grass in doin' so, eats the bottom part sometimes, an' lets th' top part float down fer th' brents teh eat."

"The brant makes the broadbill gather his dinner," said Bradley.

"Yes; thet be 'bout so. The brents don' dive, an' they allus follers th' broadbills teh get th' grass they pulls up."

" Broadbill 's your favorite duck when cooked, then, Captain ?" from Corbin.

"Not azacly; I favor blackduck ahead of 'em all, tho' nex' teh th' blackduck I likes canvasback."

And so the three jovial men talked on 


\section{The Wild-Fowlers}

subjects manifold for another hour, when the Captain, suddenly dropping his field glass with the remark, "Thet 'ere boy be wavin' his cap teh come in," made off in the dingy, poling with all his might toward the battery.

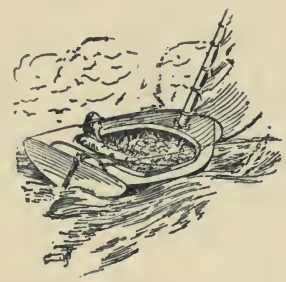

"The water is the eldest daughter of the creation, the element upon which the Spirit of God did first move."

ISAAK WALTON. 



\section{IX}

The Contemplative Sportsmen 


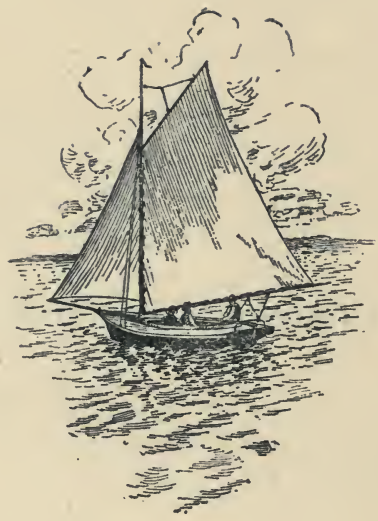

146 


\section{IX}

\section{The Contemplative Sportsmen}

"Oh! gentlemen legislators, gentlemen sportsmen, 'reform it altogether.'"

Frank Forester.

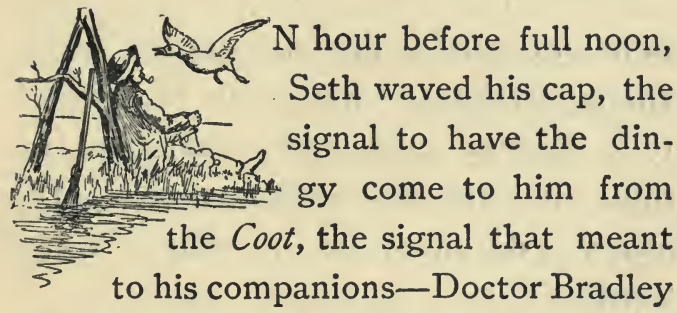
and Doctor Corbin, who were snugly housed in the sloop's cozy cabin - that he had had his share of shooting for the day; so he was taken aboard and the old Captain and Adam began rigging out the double battery, in which the two fat doctors were to enjoy the afternoon and early evening's sport.

Seth's friends all welcomed him with 


\section{I48 The Wild-Fowlers}

hot coffee and a great assortment of bay food and bacon, and the young sportsman's appetite was equal to the offering. His cheeks glowed with a rosy tan, his clear blue eyes twinkled merrily, and his ringing laughter and general demeanor showed clearly the good effects of pure air and out-door exercise.

"Good Lor', boy," said Corbin to Seth as he prepared a hot clam broth for his young friend, "you must be frozen! It 's mighty cold here, and must be colder in that ice-box out there. My, how you do shoot, boy! Where 'd you learn ?"

"I don't know, exactly," responded Seth; " out west, I imagine, when quite young. I had a careful teacher in my father. He began with me almost from the cradle. I 've shot a great many times as a boy with the old gentleman in a duck boat hidden on marshy points down the Detroit River somewhere around Grosse Isle when that territory was a 


\section{The Wild-Fowlers}

wilderness. I 've seen the governor bag twenty canvasback and as many redhead in a morning. It must have been fully thirty years ago, when such sporting characters as Seth Green, Ira Paine, Joseph Christian, John Parker, Edward Gilman, Colonel Evarts, Governor Bagley, Cook Cousins, Colonel Mark Flannigan, and many other good spirits of these days were in their prime. Those were great days for game. My father, a resident of Detroit, - he lived there for forty years,-used to bag wild turkey, woodcock, grouse, and quail within an hour's drive of the spot where the Soldiers' Monument now stands.

"I never shot ducks on salt water before to-day," continued Seth, "but I like the sport, and don't think it 's easy play in the battery. Many of the bunches of broadbill went by at a speed of fully a mile a minute, and the redhead that were favored by the wind must have winged it quite as fast." 
"Well, is it unsportsmanlike-this battery shooting - as you read me in the chapters from Frank Forester and Robert Roosevelt ?" laughed Doctor Bradley.

"Yes, I think it is," replied Seth; " but I want to add that it 's no boy's play to get the game. It 's far from being easy work to kill in the battery. The water and the sky-line, the immense open space and the clear atmosphere, tend to deceive you in the matter of distance. The ducks appear to be fully half as near to you as they, really are, and a tyro at the play would certainly shoot before the proper moment, as I invariably did the first full hour this morning. The shooting is quite as honorable, I think, as any sort of game shooting. The only unsportsmanlike feature in the method is the fact that the battery, and consequently its occupants, the shooters, are located directly on the fowls' feedinggrounds. I would rather shoot from a point while the game is on its way or 
coming from the places it frequents in feeding. Besides, the practice is in vogue in April as well as during all the autumn and winter months, and this is a ruinous law. No migratory game-no game of any sort-should be bagged in the spring of the year, when they are mating and preparing to breed. All forms of game shooting should be limited to the fall and winter periods. Even this restriction would not save many important species from being exterminated, the same as the American bison, the beaver, and the wild pigeon were destroyed. But, while I think of it, another point about battery shooting - the trick the birds have of getting right into the decoys without your seeing their approach. Of course, many come from behind you, and the rule of lying flat on your back prevents you from keeping a lookout in this direction, but the number of bunches, large flocks, pairs, and single birds that come from the very direction your face is 
turned to and fly right in front of your gun muzzles before you discover them is astounding. And these are the birds most often missed-these and the ones shot at out of range by the gunner incorrectly estimating the distance through the deceptions I have mentioned."

"Yes, perhaps April should be excluded from the legal period," said Doctor Bradley; “ but I presume it is included for two reasons - brant [brent geese] are more plentifùl hereabout during this month than at any other time, and the fact that our ducks, geese, snipe, and plover do not nest 'here," - and the Doctor helped Seth to his third bowl of coffee, while poor jolly Corbin, jokingly distracted at the young man's extravagant appetite, began the frying of a new batch of eggs and half a pan of thin slices of bacon.

" Now that is true," replied Seth; "the wild fowl and bay birds do not nest in these latitudes, though, to be precise, we 
should exclude the clapper rail, the little spotted sandpiper, and one or two other small species. A few pairs of these pipers do nest along our tide creeks and trout streams, and the clapper rail [meadow hen] is a regular breeder on our salt meadows. But, as you say, the great body of wild fowl and shore birds do not breed here. They visit us on their way to the great nesting grounds in the far north. They flight in here for a little rest and food, and they are easily taken by hundreds-aye, by thousands. They are gentle in the spring-time when they are engaged in selecting their mates, and they do not possess a true game quality, in flavor or character."

"Quite true, quite true," cried both the doctors in chorus, Doctor Bradley adding: "We all feel that way about spring gunning, and we will not be sorry when April is counted among the months of closed time. Some of the greedy fellows gun for snipe and plover all through 


\section{I54 The Wild-Fowlers}

the month of May when the law says they shall not give trigger. Even many of the baymen who derive a living by guiding sportsmen to the snipe and plover blinds take out men and boys to shoot in May. The guide should be the last man on earth to disregard the law-to slaughter in mating time-for without the game he could n't make a living outside of his eel pots and clam holes."

"Yes," added Corbin, "April is bad enough, and though it is quite lawful to gun for ducks and geese during this month-the season ends May Ist-the Doctor and I have long contemplated giving up the practice. We would n't have come out here this April only for you-we wanted to introduce you to the Great South Bay and at the same time discuss the very matter now in hand. So, having accomplished our purpose without breaking any law, mind you, and having, as you shall see later on, really performed an act for the good of both game and 
gunner, no more spring shooting for us from now on, law or no law."

"Thank you, my good friends," replied Seth. "And let us hope we can some day arrange matters so that our snipe, plover, duck, and geese may be spared here by all sportsmen in their spring migration, - their journey from the south where they winter to the north where they breed,-for when this is done they will return here with their herds of young in the late summer, autumn, and early winter months when on their way to the south again, and we will all have better sport at better conditioned fowl. To shoot a bird in the spring-time is like destroying, as Shakespeare says, the vine for one sweet grape. Every duck or goose or snipe or plover shot in the mating season means the destruction of the brood it would raise for us, as well. But I must say I like bay shooting, and I hope to have lots of it, in the proper season,- the fall and winter months, - and from a reedy 


\section{I56 The Wild-Fowlers}

point off one of those many beautiful channel islands in the western part of the bay."

"It is time sportsmen united in an effort to save our shore birds and wild fowl before they are utterly exterminated," said Corbin. "I hope they won't wait until it is too late, as they did in the case of the pigeon, buffalo, and beaver."

"Four new laws would insure good wild-fowling and bay snipe and plover shooting for many years," responded Seth; "or, at least, save the species from being killed off entirely: (I) Restrict battery shooting to waters that do not flow over actual feeding-grounds, or do away with the machine altogether; (2) abolish spring shooting-let the fowl season end April Ist instead of May Ist; (3) rid the land of the plumage gatherer, the brutal destroyer who tears off wings and heads of all species of birds, in and out of season, for the millinery store; (4) put down the 


\section{The Wild-Fowlers}

market shooter-prohibit the sale of game. With these laws in full force our migratory game birds would be spared the fate of the wild pigeon, and the gentle sportsman's rural pleasures would be preserved forever, for the man of the wing gun of to-day is a gentleman and is too wise to the growing scarcity of his game to wantonly take more birds than an honest outing entitles him to. I don't believe any sportsman ever takes more than a gentle share of game, bird, quadruped, or fish, though there are indifferent shooters and fishermen who judge their day by the size of their creel or game-bag, but they are not sportsmen and have no more right to the title than the marketman and plumage gatherer should be termed sportsman. The fellow who shoots or fishes for mere quantity is a bungler, a rowdy, and a dangerous person, no matter what his reason may be-that he kills for the market, that he gathers feathers for the woman's hat, or that he must display a 
${ }^{8}{ }^{8}$ The Wild-Fowlers

greedy bag to save his reputation as a mighty fieldman or angler. Such destroyers may not have been so objectionable a hundred years ago, when game swarmed the land, but their practices today, when game is so scarce and becoming scarcer every day, are criminal, and sportsmen must join forces and make laws say so. But, enough of this for the present, say I. Do you gun the same in winter as in the fall, Doctor, here in the Great South Bay?"

"Yes; pretty much," replied Doctor Bradley. "Some of the baymen and one or two hardy sportsmen I know of shoot in mid-winter, even when the bay is filled with snow and ice. They then dress all in white and look like just so much snow, and-_."

“ An' kill lots o' birds," added the old Captain; "more ' $n$ is shooted in th' spring er any other time o' year, but it 's cold sport, mighty cold, I tell yer. But come, genelmen, yer double battery be 


\section{The Wild-Fowlers}

nigh ready," added the bayman, nodding to the two doctors, " an' yer want teh be right smart now an' do es well es Mister Fieldin' did this mornin'." And the two old sportsmen began adjusting their warm top jackets and rubber boots.

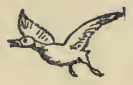

" To be glad of life, because it gives you the chance to love and to work and to play and to look up at the stars; to be satisfied with your possessions, but not contented with yourself until you have made the best of them ; to despise nothing in the world except falsehood and meanness, and to fear nothing except cowardice; to be governed by your admirations rather than by your disgusts; to covet nothing that is your neighbor's except his kindness of heart and gentleness of manners ; to think seldom of your enemies, often of your friends, and every day of Christ ; and to spend as much time as you can with body and with spirit, in God's out-of-doors. These are little guide-posts on the footpath to peace."-HeNRY van DyKe. 



\section{X}

\section{The Last Chapter}




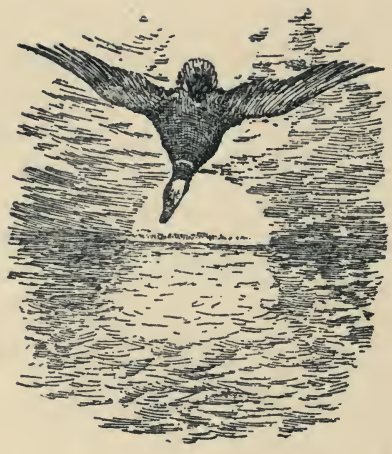

I62 


\section{$\mathrm{X}$ \\ The Last Chapter}

" Did more worship in the open air, under the broad ciborium of heaven, the social standards of health and morality would rise simultaneously."

R. G. Pearson.

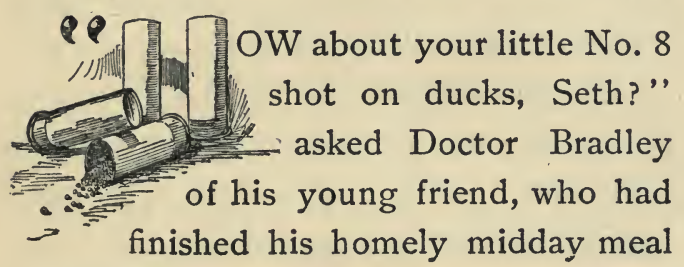

in the tiny cabin of the sloop and was cutting off the end of a great black cigar Doctor Corbin had helped him to out of the sportsmen's leather case.

Old Grieb was tugging away at various ropes and other things in the decoy hole in an endeavor to make room for the single battery to be taken aboard as soon as the double machine was fully adrift. 
I64 The Wild-Fowlers

Little Adam, the Captain's ruddy son, was busy too, and it was a treat to Seth and his companions to observe with what remarkable good-nature he received his father's boisterous orders.

"Yes," echoed Corbin, as the three men, observing the old bayman coming toward the cabin, tried their best to appear unconcerned in his quarrelling with the boy; "yes, tell us how the quail shot worked on the ducks, Seth."

"So the Captain has told you of our conversation on deck last night, has he ?" said Seth. "Well, the load, a trifle over an ounce of No. 8 shot with but two and a half drams of nitro powder behind it, performed as well as I expected, but I must admit I prefer a larger-size pelletsay a No. 4 for brant and the Canada geese, and No. 6 for all the ducks, though I was taught to use No. 4 on ducks, and a larger size, $\mathrm{BB}$, I think, on geese. $\mathrm{My}$ father used No. 4 on canvasback, redhead, and broadbill—called bluebill in the 


\section{The Wild-Fowlers}

western part of the country, and blackhead in the south-and he was a great duck shooter. Still, I think he 'd have done as well, perhaps better, with No. 6 at the ducks."

"And your 12-gauge gun-did it do as well as a ro-gauge would have done?" asked Bradley.

" Better-for me," replied Seth, " but I do not say it is a better gauge than other gauges in the hands of all men, because all men are not alike in their consideration of wild-fowling. I think all gentle sportsmen will approve of my idea of the sport, but all men who use shotguns are not sportsmen, any more than the bungler who fishes with a chalk line and a horseshoe sinker may be termed an angler; so I shall not be without an arguer or two when my discourse reaches certain ears. I can kill as far with my I2gauge, or even a 14- or 16-gauge, as with a larger bore, so why should I use a big, heavy, clumsy Io-gauge, since I do not 


\section{I66 The Wild-Fowlers}

ply my tarpon rod in trout fishing ? No sportsman of to-day cares to bring down more than one bird with each barrel, and an ounce of shot is all any decent gunner need use for that purpose. My I6-gauge will throw that ounce load as far and as straight as any man's ro-gauge, and I have a bright new thousand-dollar note to back the statement."

"Stage money or genuine goods, Seth ?" laughed Bradley.

"Whichever you choose, Doctor; but if you wager, or if any sportsman takes the wager, it will be on the same side my money lies. The flock shooter-the fellow who guns for the markets and millinery stores and who can't afford an ounce of shot on but one bird-may stake his purse the other way, and if he does and I 'm his opponent, he 'll lose.

"I am aware that this declaration and, of course, my views in general on this subject, as expressed here, would not meet the approval of the shoot-at-the- 


\section{The Wild-Fowlers}

whole-flock fellow, and the smaller fry of gun dealers who have a large assortment of market-size guns in stock,-some of them even handle an 8-bore, and I know a bayman whose best patron shoots a 4bore,-nor will my ideas be approved of by the little hole-in-the-wall ammunition shops and at the dry-goods-store sporting counters, where quantity in sales rather than quality is the standard motto, but what I say regarding the I6-gauge arm and its small charges is true none the less, and though the time is not quite ripe for the general adoption of the small wing gun in place of its larger cousins, the better class of gunmakers will soon recognize the truth of the matter, just as they did in the case of the flintlock and the cap gun, the muzzleloader and the breechloader, and the hammer and the hammerless guns."

"I guess you 're right, boy," said Corbin, "but, by my true word, the Doctor and I don't worry much about the thing, 


\section{I68 The Wild-Fowlers}

anyway. We 've had our day. Bradley's too old and I 'm too stout to find it worth any great difficulty to perfect the matter in our cases. Ha! cases-not gun-cases. No pun intended, I assure you."

" But Seth is quite right," said Doctor Bradley, " though, as you say, Doctor, I am too old to become excited over anything nowadays, and I will stand by him in this gun question, but he need n't think his immediate argument has settled the affair in my mind. I have for years seen the thing just as he pictures it, though the advent of nitro powder has increased my belief, I will admit."

" Thank you, Doctor," answered Seth; " and thank you, Doctor Corbin. Now a word more. Old and fat as you both are, you must admit you love this gun talk, and you 'd both work like young race horses to work it into practical service if you were put to the test; you know you would, indifferent as you claim to be. I use my 16-gauge on snipe, quail, and 
woodcock, and Loomis and Stoltz claim I do quite as good shooting as any of the IO- and I2-gauge guns of their acquaintance. I can't for the life of me see any good reason for the use of a lo-gauge in any sort of sporting this side of Africa, since at single wing game the $12-, 14-$, and 16- are quite as killing. Why burn unnecessary powder? Why carry an eightor nine-pound gun when an arm of six pounds with its compact ammunition will do the work-the sportsman's work ? Of course, a ro-gauge, loaded with heavy charges of shot, will kill more birds in a bunched flock, but sportsmen do not kill more than one bird at a single discharge, and they do not shoot at the bunches. This is the market-men and milliners' business. I am not advocating a business gun or a business load or a business pursuit. My dealings are with the sportsman and his arm and ammunition. Why ride a clumsy thirty-pound wheel when one of eighteen pounds serves better? Why use a 


\section{70 The Wild-Fowlers}

mule-teamster's lash on a horse-lover's trotting team? Why play tennis with a cannon-ball ? Why, as an angler, would you drag a market-fisherman's net for brook trout, or flail a surf rod along the tiny mountain stream? The gun-clerk's excuse, 'The small gun recoils too much,' will not do in these practical days of nitro powder and perfect wadding, though it may serve to sell his large-bore overstock, and the wheelmaker's plea, 'The light wheel is not strong enough for safe riding,' may help sell the old, heavy machines; but the well informed rider knows the light wheel is the correct article for comfort and good riding."

" Why dek yer use th' 12 instead of th' I6 on ducks, then, Mr. Fieldin '?' asked Captain Grieb, who had come up to the little group to announce the readiness of the double battery.

" Only because I possess the two guns, Captain Grieb. The I6 kills ducks, as I shoot them-singly-as well as the 12. 
The flock shooter-the fellow who judges his day by the quantity of his game rather than the quality and pursuit of it-should use a cannon, just as the rowdy, who can't kill enough fish with the rod to satisfy his greedy nature, uses a net or stick of dynamite to secure his insatiable mess."

"Why not advocate a 20-gauge, Seth, and be done with it ?" put in Bradley.

"Because a 20-gauge is too small to well stand a full ounce of shot and the powder necessary to propel it, in my opinion, and one needs an ounce, but not more, for general wing shooting. I am speaking of an all-round wing gun, Doctor, not special pieces. The 20-gauge and its light charges would be nice for small bay snipe and plover-the oxeyes, ringnecks, dowitcher, etc. - but nothing else. I want my full ounce for woodcock, English snipe, quail, grouse, etc., as well as in big bay snipe and plover shooting and wild-fowling. If a man requires more birds than he can bag singly, he 's a 
pot-shot hoodlum, a milliner's-man, or a market gunner, and if one can't shoot well enough to kill on the wing with an ounce of scattering shot he should give up the sport."

"And play golf," added Corbin. "Say, Seth, did you see any blackduck ?"

"No. I don't think the blackduck often comes to the battery stool; does it, Doctor Bradley ?"

"No; it does not. That bird, though fond of salt water, is a point, creek, and pond duck. A bunch often troops by the battery stool, and I 've killed a few pairs from the sink-box in my day, but they are best taken from a point near a favorite feeding creek when the tide is low late in the day or very early in the morning. The blackduck is the greatest of wild-fowl game."

"The king of all the wild ducks," added Seth.

"Undoubtedly," continued Bradley. 


\section{The Wild-Fowlers}

" He jumps like a woodcock when flushed. I 've seen him go right up in the air twenty feet with one bound. All other wild fowl take wing ordinarily; just scurry away over the water any old way."

"Thet be kerrect," contributed old Grieb, broadly grinning with delight at the popular natural history; " an' them blackduck do know a heap site more 'n eny other bird. I thinks they sleep all day an' feeds all night jes' like the night heron. (' quock'). They rides in a great mess right out in th' open ocean in th' deep swell jes' beyon' th' breakers with a king drake an' a few ol' coots servin' es sentinels, an' they come in th' bay an' th' salt ponds an' creeks to feed when th' tide be low at night, an' early in th' mornin'. They know better ' $n$ teh come in when th' tide serves low in broad daylight. 'T ain't enybody es ken take 'em on th' wing, nuther, when they do be in range."

"No, Captain; they are the game of only the most expert fowlers, and are 
I74 The Wild-Fowlers

never bagged by the bungler or him of the cheap iron weapon," added Doctor Bradley.

" Now, genelmen," said Captain Grieb, with a rather serious change in his tone of voice, "your box be ready," and he pointed in the direction of the double battery, now anchored in the same spot the single machine had occupied all morning for Seth's special benefit, but resting with its anchor end facing in just the opposite direction in which the first battery had been put out, owing to the wind, which had swung the decoy fleet around so that they rode heads pointing up the bay instead of to the west, as when Seth shot over them.

But, reader, why prolong the narrative? The tale is told. The sportsman declares that half the pleasure of a trip afield or afloat is in the preparation, and what our sporting friends have here neglected in this respect my poor pen has tried its best to yield. The fat doctors went forth in 


\section{The Wild-Fowlers}

their battery, and they had their share of sport, though little came to bag.

"By my true soul, I was too cold to shoot well," said Corbin.

"My head was n't high enough for me to see the birds," pleaded Bradley.

And they all sat down and did full justice to a hot supper of steaming biscuits, bacon, and bay food, after which, while the sportsmen smoked their favorite cigars, little Adam cleared away the dishes and his father got out the blankets and shooting coats and spread them for the night's repose. This done, the bayman and his boy went forward into the decoy hole and made their bed of hay and tarpaulins, and-the pleasant excitement and natural exercise throughout the day fully telling upon the five good spiritsvery soon every soul aboard the sturdy Coot was soundly and snugly housed in dreamland.

THE END 


\section{Charles Bradford's Books} FOR GENTLE SPORTSMEN

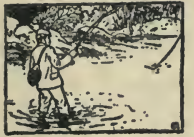

\section{THE DETERMINED ANGLER}

Depicts a fly-fisherman's paradise, and divulges many a secret of the angler's art. I6 $6^{\circ}$, illustrated (by mail, 65 cents),

60 cents.

"The most pleasant and practical and sensible volume I have ever seen of its kind."-Grover Cleveland. "Fully deserves this endorsement." $-N$. Y. Herald.

THE WILD-FOWLERS : or, Duck Shooting in the Great Lagoon.

A description of several Noted Sporting Scenes and Characters. With many practical hints concerning shot guns and ammunition, the natural history of wild fowl and the chivalric sportsman's best methods of taking the game. 16 $6^{\circ}$ (by mail, \$r.ro) . . . . . net, $\$ \mathrm{r} .00$

\section{IN PREPARATION.}

AMERICAN GAMELANDS : Haunts of the Fur, Fin, and Feather Tribes.

AMERICAN ANGLING WATERS : How to Find and Fish them.

FISHING FLIES: Their Seasons and Descriptions.

$$
\text { G. P. PUTNAM'S SONS }
$$

NEW YORK

LONDON 


\section{SPORTING BOOKS}

\section{BY THEODORE ROOSEVELT}

\section{Hunting Trips of a Ranchman}

Sketches of Sport on the Northern Cattle Plains. With numerous engravings from designs by Frost, Gifford, Beard, and Sandham. $8^{\circ}$, pp. xvi. +347 . . . $\$ 3.00$ Also, SAGAMORE SERIES, in two volumes, with frontispiece. Cloth, $16^{\circ}$, each . . . . 50 cents

Divided as follows :

I. Hunting Trips of a Ranchman

II. Hunting Trips on the Prairie and in the Mountains

"One of those distinctively American books which ought to be welcomed as contributing to raise the literary prestige of the country all over the world." $-N$. Y. Tribune.

"One of the rare books which sportsmen will be glad to add to their libraries. - Mr. Roosevelt may rank with Scrope, Lloyd, Harris, St. John, and half a dozen others, whose books will always be among the sporting classics."-London Saturday Review.

". He must be a hopeless reader who does not rise from this book with a new and vivid sense of "the fascination of the vastness, loneliness, and monotony of the prairies,' and of 'the sad and everlasting unrest of the wilderness,' of the Big Horn Mountains.

As already said, the charm about this ranchman as author is that he is every inch a gentleman-sportsman. . . "-London Spectator.

\section{The Wilderness Hunter}

With an Account of the Big Game of the United States, and its Chase with Horse, Hound, and Rifle. With illustrations by Remington, Frost, Sandham, Eaton, Beard, and others. $8^{\circ}$, pp. xvi. +472 . . . . . . . . $\$ 3.00$

$A Z_{s o}$, SAGAMORE SERIES, two volumes, with frontispieces. Cloth, $16^{\circ}$, each . . . . . . . 50 cents Divided as follows :

I. The Wilderness Hunter II. Hunting the Grisly

"A book which breathes the spirit of the wilderness and presents a vivid picture of a phase of American life which is rapidly passing away, with clear incisive force." -New York Literary News.

"For one who intends to go a-hunting in the West this book is invaluable. One may rely upon its information. But it has better qualities. It is good reading for anybody, and people who never hunt and never will are sure to derive pleasure from its account of that part of the United States, relatively small, which is still a wilderness." New York Times.

\section{G. P. PUTNAM'S SONS}




\section{SPORTING BOOKS}

\section{The Encyclopædia of Sport}

Edited by the Earl of Suffolk and Berkshire, Hedley Peek, and F. G. Aflalo. This important work is now completed in two volumes. Royal $8^{\circ}$, each with about 600 pages. With many hundred illustrations in the text, and with 20 full-page photogravure plates.

Cloth, each . . . . . . . net, $\$ 10.00$

The illustrations have been designed especially for the work by well-known artists, including J. G. Millais, C. E. Brock, J. G. Keulemanns, Archibald Thorburn, and others.

"In the 'Encyclopædia of Sport' sportsmen have in a concrete form a veritable alphabet of sport worthy of the subject and invaluable as a book of constant reference-it is specially clear, concise, and full." Outing.

"This work, which covers every branch of sport, is admirably conceived and ably executed . . . the contributors form such a representative body of sportsmen as is almost a guarantee for the quality and completeness of the text . . . the photogravure plates are a most attractive feature of the work, while many of the text illustrations are admirable."-The Fishing Gazette.

\section{The Art of Revolver Shooting}

\section{By WALTER WINANS}

(Vice-President of the National Rifle Association of Great Britain)

With nearly 200 Illustrations from Original Drawings by the Author, and from photographs specially taken for the book.

Royal $8^{\circ}$. Gilt top . . . . . . . net, $\$ 5.00$

"Mr. Winans's book is meant primarily to instruct, and he begins at the elements of his 'art.' The evolution of the revolver is sketched, after which the learner is told how to select, handle, and take care of the weapon. Special chapters are devoted to the Bisley rules and competitions, to practice and training, to gallery shooting, stage shooting, trick shooting, game shooting, pigeon shooting, to shooting from a bicycle, and what not. In short, about every question likely to be asked touching the uses of the revolver is replied to clearly and authoritatively in this exhaustive book."-Chicago Dial.

\section{G. P. PUTNAM'S SONS}

NEW YORK

LONDON 


\section{BOOKS FOR THE COUNTRY}

\section{OUR INSECT FRIENDS AND FOES}

How to Collect, Preserve and Study Them. By Belle S.

Cragin. With over 250 illustrations. $12^{\circ} \$ 1.75$.

\section{AMONG THE MOTHS AND BUTTERFLIES}

By Julia P. BALlard. Illustrated. $8^{\circ}, \$ 1.50$.

\section{BIRD STUDIES}

An Account of the Land Birds of Eastern North America. By William E. D. ScotT. With i66 illustrations from original photographs. $4^{\circ}$, leather back, gilt top, in a box, net $\$ 5.00$.

\section{WILD FLOWERS OF THE NORTHEASTERN} STATES

Drawn and carefully described from life, without undue use of scientific nomenclature, by Ellen Mriler and Margaret C. Whiting. With 308 illustrations the size of life. $8^{\circ}$, net, $\$ 3.00$

THE SHRUBS OF NORTHEASTERN AMERICA

By Charles S. Newhall. Fully illustrated. $8^{\circ}, \$ \mathbf{1} .75$

\section{THE VINES OF NORTHEASTERN}

\section{AMERICA}

By Charles S. Newhall. Fully illustrated. $8^{\circ}, \$ 1.75$.

\section{THE TREES OF NOTHEASTERN}

\section{AMERICA}

By Charles S. Newhall. With illustrations made from tracings of the leaves of the various trees. $8^{\circ}, \$ 1.75$.

G. P. PUTNAM'S SONS

New York and London 



\section{UNIVERSITY OF CALIFORNIA LIBRARY BERKELEY}

Return to desk from which borrowed.

This book is DUE on the last date stamped below.

$5 \tan 52] \mathrm{K}$

DEC $5 \quad 195240$

P: 01954.10

15Whar55AM

MAR 1 1955 LU

AUG $119 \overline{7} \overline{7} \overline{\mathbf{7}} \dot{9}$

REC'D LD JUL 24 '72 -8 PM 3

UNIV. OF CA 
YB 1591:

M̄312309

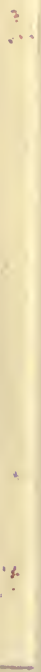


the

(x)

Fin

2.

(1)

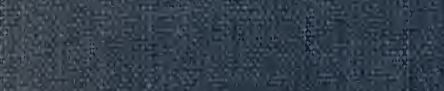

(60)

6.7.

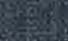

$\rightarrow+250$.

Wing

Y.

19

(1)

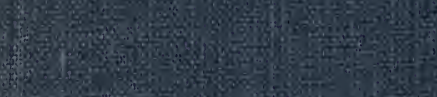

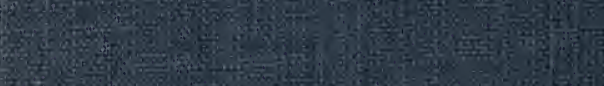

